\title{
Dietary trans 10, cis 12-conjugated linoleic acid reduces the expression of fatty acid oxidation and drug detoxification enzymes in mouse liver
}

\author{
Reuven Rasooly ${ }^{1}$, Darshan S. Kelley ${ }^{1 *}$, Jeff Greg ${ }^{2}$ and Bruce E. Mackey ${ }^{3}$ \\ ${ }^{1}$ Western Human Nutrition Research Center, ARS, USDA, Davis, CA, USA \\ ${ }^{2}$ Department of Pathology, University of California Medical Center, Sacramento, CA, USA \\ ${ }^{3}$ California, Western regional Research Center, ARS, USDA, Albany, CA, USA
}

(Received 13 March 2006 - Revised 8 June 2006 - Accepted 28 June 2006)

\begin{abstract}
Mice fed diets containing trans 10, cis 12 (t10, c12)-conjugated linoleic acid (CLA) develop fatty livers and the role of hepatic fatty acid oxidation enzymes in this development is not well defined. We examined the effects of dietary cis 9, trans 11-CLA (c9, t11-CLA) and t10, c12-CLA on the expression of hepatic genes for fatty acid metabolism. Female mice, 8 weeks old, (six animals per group) were fed either a control diet or diets supplemented with $0.5 \% \mathrm{c} 9, \mathrm{t} 11$ - or $\mathrm{t} 10, \mathrm{c} 12$-CLA for 8 weeks. DNA microarray analysis showed that t10, c12-CLA increased the expression of 278 hepatic genes and decreased those of 121 genes ( $>2$-fold); c9, t11-CLA increased expression of twenty-two genes and decreased those of nine. Real-time PCR confirmed that t10, c12-CLA reduced by the expression of fatty acid oxidation genes including flavin monooxygenase (FMO)-3 95\%, cytochrome P450 (cyt P450) 69\%, carnitine palmitoyl transferase 1a $77 \%$, acetyl CoA oxidase (ACOX) 50\% and PPAR $\alpha$ $65 \%$; it increased the expression of fatty acid synthase by 3.5 -fold $(P<0.05$ for all genes, except ACOX $P=0.08)$. It also reduced the enzymatic activity of hepatic microsomal FMO by $40 \%$ and the FMO3 specific protein by 67\%. c9, t11-CLA reduced FMO3 and cyt P450 expression by $61 \%(P=0 \cdot 001)$ and $38 \%(P=0 \cdot 06)$ and increased steoryl CoA desaturase transcription by $5 \cdot 9$-fold $(P=0 \cdot 07)$. Both decreased fatty acid oxidation and increased fatty acid synthesis seem to contribute to the CLA-induced fatty liver. Since FMO and cyt P450 are also involved in drug detoxification, suppression of the transcription of these genes by CLA may have other health consequences besides development of fatty liver.
\end{abstract}

Microarrays: Real-time PCR: Cytochrome P450: Flavin monooxygenase: Carnitine palmitoyl transferase: PPAR $\alpha$

Conjugated linoleic acid (CLA) is a collective term for a group of isomers of linoleic acid that have conjugated double bonds. Depending on the position and geometry of the double bonds, several isomers of CLA have been reported (Eulitz et al. 1999). Most of the published studies have used mixtures of CLA isomers, which comprised two major forms, cis 9, trans 11-CLA (c9, t11-CLA) and trans 10, cis 12-CLA (t10, c12-CLA), and a number of minor isomers. The major dietary sources of $\mathrm{c} 9$, t11-CLA are dairy products and ruminant meat, while that of 110, c12-CLA are partially hydrogenated vegetable oils from margarines and shortenings (McGuire et al. 1999).

Feeding a mixture of CLA isomers to animal models altered blood lipids, atherogenesis, diabetes, body composition, chemically induced carcinogenesis and immune cell functions (Belury, 2002). Diets containing CLA reduced the amount of adipose fat in several species including rat, pig, hamster, chicken and mouse (Kelley \& Erickson, 2003; Tricon et al. 2005). The loss of adipose tissue in mice was associated with a several-fold increase in the amount of fat stored in the liver (Belury \& Kempa-Steczko, 1997; Park et al. 1999; Tsuboyama-Kasaoka et al. 2000; Clement et al. 2002;
Degrace et al. 2003; Kelley et al. 2004; Poirier et al. 2005). $\mathrm{We}$, as well as others, have previously reported that $\mathrm{t} 10$, c12-CLA is the isomer that is responsible for the development of fatty liver in mice (Park et al. 1999; Clement et al. 2002; Kelley et al. 2004). Decreased expression of adipocytokines and up regulation of the expression and activity of the lipogenic enzymes acetyl-CoA carboxylase (ACC), fatty acid synthase (FAS), malic enzyme (ME), stearoyl CoA desaturase (SCD)- 1 and $\delta 5$ and 6 desaturases have been postulated to be the underlying mechanisms that lead to the development of fatty livers in mice fed diets containing CLA (TsuboyamaKasaoka et al. 2000; Degrace et al. 2003, 2004; Takahashi et al. 2003; Warren et al. 2003; Javadi et al. 2004; Ide, 2005; Poirier et al. 2005). Expression of mice hepatic fatty acid oxidation genes also increased in three studies with a mixture of CLA isomers (Takahashi et al. 2003; Javadi et al. 2004; Ide, 2005) and in one study with t10, c12-CLA (Degrace et al. 2004). Authors who supplemented the mouse diets with the purified t10, c12-CLA expected a reduction in hepatic fatty acid oxidation because CLA increased the hepatic concentration of malonyl CoA and the sensitivity of carnitine palmitoyl transferase (CPT)-1 to inhibition with malonyl CoA

\footnotetext{
Abbreviations: ACC, acetyl-CoA carboxylase; c9, t11-CLA, cis 9, trans 11-CLA; CLA, conjugated linoleic acid; CPT, carnitine palmitoyl transferase; cyt P450, cytochrome P450; FAS, fatty acid synthase; FMO, flavin-containing monooxygenase; ME, malic enzyme; SCD, stearoyl CoA desaturase; t10, c12-CLA, trans 10, cis 12-CLA.

* Corresponding author: Darshan Kelley, fax +1 530752 5271, email dkelley@whnrc.usda.gov
} 
(Degrace et al. 2004). Development of fatty liver and increased hepatic fatty acid oxidation is a paradox that may be true, but normally we would expect hepatic fatty acid oxidation to be reduced if more fat is stored in the liver. None of the published reports has used the microarray technology to systematically examine all the hepatic genes involved in fatty acid metabolism, whose expression may be modulated by CLA-containing diets.

The purpose of the present study was to use a comprehensive approach to identify all the mouse liver genes involved in fatty acid oxidation $(\alpha, \beta$ and $\omega)$ and synthesis, whose expression may be altered by feeding diets containing CLA preparations enriched in one of the two common isomers (c9, t11-CLA and t10, c12-CLA). We used the Affymetrix Inc. (Santa Clara, CA, USA) microarray chips to identify the genes whose expression was altered by CLA. Changes in gene expressions detected by microarrays were confirmed by quantitative real-time PCR. The expressions of several genes involved in fatty acid oxidation and synthesis were altered by the feeding of t10, c12-CLA isomer. The largest reduction in gene expression was found for the two microsomal enzymes, cytochrome P450 (cyt P450) and flavin-containing monooxygenase (FMO)-3; these enzymes are involved in microsomal $\omega$ oxidation of fatty acids and the detoxification of a variety of xenobiotic compounds (White et al. 1978; Falls et al. 1997; Orellana et al. 1998; Reddy \& Hashimoto, 2001; Krueger \& Williams, 2005; Sanders et al. 2005; Weng et al. 2005). Under normal conditions microsomal fatty acid oxidation represents less than $10 \%$ total fatty acid oxidation; however, during starvation and diabetes the contribution of this pathway in overall hepatic fatty acid oxidation is significantly increased (Orellana et al. 1998). Microsomal fatty acid oxidation may have a significant role in fatty acid oxidation in mice fed diets containing t10, c12CLA, because this isomer produces diabetes-like symptoms of increased blood glucose and insulin resistance (Poirier et al. 2005). Expression of cyt P450 and FMO3 is altered by several compounds that induce non-alcoholic fatty liver (Krueger \& Williams, 2005) and FMO3 is the major isoform of FMO found in human liver (Falls et al. 1997). The affect of CLA on the expression of these genes has not been previously published. We, therefore, also investigated the combined enzymatic activity of all the hepatic microsomal FMO and amount of the FMO3 specific protein. The present results show that diets containing the t10, c12-CLA reduced FMO activity, FMO3 specific protein and the transcription of several genes involved in fatty acid oxidation.

\section{Materials and methods \\ Conjugated linoleic acid isomers and diets}

Highly enriched c9, t11-CLA and t10, c12-CLA isomers in the form of NEFA were a kind gift from Natural ASA, Hovdebygda, Norway. The analytical data for these isomers were provided by the supplier and confirmed by GLC in our laboratory (Warren et al. 2003; Kelley et al. 2004). The preparation enriched in c9, t11-CLA contained (\%): c9, t11-CLA 84.6; $\mathrm{t} 10$, c12-CLA 7.7; 18: $1 n-9$ 3.8; t9, t11-CLA + t10, t12CLA 2.0; other fatty acids 1.9 . In the preparation enriched in $\mathrm{t} 10$, c12-CLA, this isomer was 88.1\%; $\mathrm{c} 9$, t11-CLA
$6.6 \% ; \mathrm{t} 9, \mathrm{t} 11-\mathrm{CLA}+\mathrm{t} 10, \mathrm{t} 12-\mathrm{CLA} 2.5 \% ; 18: 1 n-91.1 \%$; other fatty acids $1.7 \%$.

The concentration of CLA used in the present study was 0.5 weight $\%$ of the diet, which is comparable to the concentrations used in previous studies with rodent models, which ranged from $0 \cdot 1$ to 1.5 weight $\%$ of a mixture of CLA isomers. AIN-93G, high carbohydrate, mouse diet was used as the basal diet. The nutrient and fatty acid composition of this diet has been previously reported (Warren et al. 2003; Kelley et al. 2004) and is shown in Table 1. For the two CLA-containing diets, CLA isomer-enriched oils were added by replacing $5 \mathrm{~g} / \mathrm{kg}$ maize oil with an equivalent amount of the CLA source. Diets were constantly flushed with $\mathrm{N}$ gas while being gently mixed in a blender. Diets were packaged in $30 \mathrm{~g}$ aliquots, flushed with $\mathrm{N}$ gas and stored at $-20^{\circ} \mathrm{C}$. Fresh dietary packets were served each day. The animal protocol was approved by the Animal Use Committee at the University of California, Davis.

\section{Animals, feeding and tissue collection}

Eighteen, 8 week old, pathogen free C57BL/6N female mice were purchased from Charles River (Raleigh, NC, USA). Female mice were chosen because of their docility for housing in groups. They were maintained in a sterile air curtain isolator at the animal facility of the University of California, Medical School with controlled temperature $\left(25^{\circ} \mathrm{C}\right)$ and light and dark cycle ( $12 \mathrm{~h}$ each). All animals were fed the laboratory chow diet for the first $7 \mathrm{~d}$, then divided into three groups of six each and fed the experimental diets for $56 \mathrm{~d}$. The dose of CLA and the duration of its feeding used in the present study are the same as we have used previously (Warren et al. 2003; Kelley et al. 2004), which are well within the ranges used by many other investigators. Details regarding animal handling, killing, tissue collection and storage have been published (Warren et al. 2003; Kelley et al. 2004).

\section{Real-time PCR}

Total RNA from approximately $100 \mathrm{mg}$ liver slices was extracted by using Trizol reagent (Invitrogen, Carlsbad, CA, USA). This RNA ( $1 \mu \mathrm{g}$ ) was denatured and used to synthesize

Table 1. Composition of the basal diet*

\begin{tabular}{lc}
\hline Ingredient & $\mathrm{g} / \mathrm{kg}$ \\
\hline Maize starch & $417 \cdot 5$ \\
Casein & 200 \\
Dextrinized maize starch & 132 \\
Sucrose & 100 \\
Maize oil & 50 \\
Fibre source (cellulose) & 50 \\
Mineral mix (AIN-93G) & 35 \\
Vitamin mix (AIN-93) & 10 \\
Cystine & 3 \\
Choline bitartrate & $2 \cdot 5$ \\
c9,t11-CLA & 0 \\
t10,c12-CLA & 0 \\
\hline
\end{tabular}

c9,t11-CLA, cis 9, trans 11-conjugated linoleic acid; t10,c12-CLA, trans 10, cis 12-conjugated linoleic acid.

${ }^{*}$ For details of diets and procedures, see p. 59. 
cDNA by using an Invitrogen pre-amplication kit. After the first strand cDNA synthesis the RNA templates were degraded by treatment with RNase $\mathrm{H}$. Specific primers for different enzymes were designed based on published full-length cDNA sequences (Table 2). The PCR reactions were performed in a programmable thermal cycler (denaturation at $94^{\circ} \mathrm{C}$ for $3 \mathrm{~min}$ followed by 40 cycles, denaturation at $94^{\circ} \mathrm{C}$ for $30 \mathrm{~s}$, annealing at $56^{\circ} \mathrm{C}$ for $30 \mathrm{~s}$ and extension at $72^{\circ} \mathrm{C}$ for $30 \mathrm{~s}$ followed by final extension of $72^{\circ} \mathrm{C}$ for $7 \mathrm{~min}$ ). The PCR products were analysed by electrophoresis in $3 \%$ agarose gels and stained with ethidium bromide. The amplicons were cloned into PCR2.1 plasmid vector (Invitrogen) and transformed into Escherichia coli competent cells by heat-shock. Cells were grown in Luria broth (LB) medium for $16 \mathrm{~h}$. White colonies were picked and grown and plasmid DNA from these transformed colonies were isolated and analysed for presence of the genes inserted. The insertions were verified by digestion with EcoRI restriction enzyme. These plasmids were sequenced using M13 reverse and M13 forward primers. The purified plasmids were serially diluted and used to generate the standard curve.

Real-time quantitative PCR was performed using a LightCycler rapid thermal cycler system (Roche Diagnostics Ltd, Palo Alto, CA, USA) according to the manufacturer's instructions. $\beta$ Actin and hypoxanthine-guanine phosphoribosyl transferase 1 was used as the housekeeping gene and results for gene expression determined by real-time PCR are expressed as ratios between the RNA for the gene of interest and that for $\beta$ actin and hypoxanthine-guanine phosphoribosyl transferase 1 . Reactions were performed in a $20 \mu \mathrm{l}$ volume with $0.5 \mathrm{~nm}$ primers and $4 \mathrm{~nm}-\mathrm{MgCl}_{2}$, dNTP, Taq DNA polymerase and buffer. The following programme was used to carry out the reaction: $30 \mathrm{~s}$ denaturation step $\left(94^{\circ} \mathrm{C}\right)$ followed by 40 cycles with a $95^{\circ} \mathrm{C}$ denaturation for $1 \mathrm{~s}$; annealing for $5 \mathrm{~s}$ at $56^{\circ} \mathrm{C}$; extension at $72^{\circ} \mathrm{C}$ for $17 \mathrm{~s}$. To confirm specific amplification, the PCR products from each primer pair were subjected to a melting curve. The melting curve was determined by holding the reaction at $55^{\circ} \mathrm{C}$ for $10 \mathrm{~s}$ and then heating slowly to $94^{\circ} \mathrm{C}$ with a linear rate of $0 \cdot 2^{\circ} \mathrm{C} / \mathrm{s}$ while the fluorescence emitted was measured. Melting curves were generated by plotting fluorescence against temperature. All assays were carried out in duplicate. Melting curve analysis demonstrated that each of the primer pair described amplified a single product with a distinct melting temperature. The predicted length of each product was confirmed by agarose gel electrophoresis.

\section{DNA microarray analysis}

Because of the high cost of the microarray chips, this analysis was performed only on two animals per group; however, the real-time PCR were performed on six animals per group. We performed DNA microarray analysis using Affymetrix Mouse GeneChips (430A 2.0 Array, representing 14000 genes) to determine the liver genes whose expression was altered by the diets containing CLA. Total RNA was extracted from the livers of mice fed control and CLA-containing diets with the TRIzol reagent; its quality and integrity were determined utilizing an Agilent 2100 Bioanalyzer (Agilent Technologies, Palo Alto, CA, USA) and absorbance at A260/A280. Only high quality RNA, having a 28S/18S rRNA ratio of $1.5-2.0$ and an A260/280 absorbance ratio of 2 , was utilized for further experimentation. It was further purified with RNAeasy silica columns (Qiagen, Valencia, CA, USA). RNA was converted to double-stranded cDNA, which was then converted to biotin-labelled cRNA by in vitro transcription labelling with a HighYield ${ }^{\mathrm{TM}}$ BioArray $^{\mathrm{TM}}$ RNA Transcript Labeling Kit (Enzo Diagnostics, Farmingdale, NY, USA). The quality of in vitro transcription and

Table 2. Sequence of primers used for quantitative real-time PCR analysis*

\begin{tabular}{|c|c|c|c|c|}
\hline Target gene & Primer sequence & Affymetrix no. & Genbank accession no. & Primer location (from $5^{\prime}$ end of cDNA) \\
\hline$\beta$ Actin & $\begin{array}{l}\text { 5'-TCATGAAGTGTGACGTTGACATCCGT-3' } \\
\text { 5'-CCTAGAAGCATTTGCGGTGCACGATG-3' }\end{array}$ & M12481_5_at & NM007393 & $\begin{array}{c}925-950 \\
1209-1184\end{array}$ \\
\hline FMO3 & $\begin{array}{l}\text { 5'-ACTTTGCCTTCTGTAAACGACATGA-3' } \\
5^{\prime} \text {-GAACTTTACTGACGACACGCGTCT-3' }\end{array}$ & 1449525_at & NM_008030 & $\begin{array}{l}1229-1253 \\
1553-1530\end{array}$ \\
\hline Cyt P450 & $\begin{array}{l}\text { 5'-GGAGAGACGCTGCTCTACTACGG-3' } \\
\text { 5'-ATACATCCAGCGAGTAGCGGC-3' }\end{array}$ & 1449316_at & NM_008898 & $\begin{array}{l}1724-1746 \\
2081-2061\end{array}$ \\
\hline CPT1a & $\begin{array}{l}\text { 5'-GGGAGGACAGAGACTGTACGCTC-3' } \\
\text { 5'-TGTAGGAAACACCATAGCCGTCAT-3' }\end{array}$ & 1434866_x_at & BC054791 & $\begin{array}{l}1865-1878 \\
2241-2218\end{array}$ \\
\hline ACOX & $\begin{array}{l}\text { 5'-GGTGGGTGGTATGGTGTCGTAC-3' } \\
\text { 5'-CAAAGACCTTAACGGTCACGTAGTG-3' }\end{array}$ & 1416408_at & NM_015729 & $\begin{array}{l}1682-1703 \\
1959-1935\end{array}$ \\
\hline PPAR- $\alpha$ & $\begin{array}{l}\text { 5'-AGGCAGATGACCTGGAAAGTC-3' } \\
\text { 5'-ATGCGTGAACTCCGTAGTGG-3' }\end{array}$ & 1449051_a & NM_011144.2 & $\begin{array}{l}490-510 \\
801-782\end{array}$ \\
\hline FAS & $\begin{array}{l}\text { 5'-CTGAAGAGCCTGGAAGATCGG-3' } \\
\text { 5'-CCCTCCCGTACACTCACTCGT-3' }\end{array}$ & 1423828_at & NM_007988 & $\begin{array}{l}7370-7390 \\
7734-7714\end{array}$ \\
\hline ME & $\begin{array}{l}\text { 5'-AGCAGTGCTACAAGGTGACCAA-3' } \\
\text { 5'-CTCCAGGGAACACGTAGGAATT-3' }\end{array}$ & 1416632_at & NM00615 & $\begin{array}{l}1273-1294 \\
1401-1380\end{array}$ \\
\hline Hprt & $\begin{array}{l}\text { 5'-GTTGGATACAGGCCAGACTTTGTTG - }-3^{\prime} \\
5^{\prime} \text {-GAGGGTAGGCTGGCCTATAGGCT }-3^{\prime}\end{array}$ & 1448736_at & NM_013556 & $\begin{array}{l}601-625 \\
952-930\end{array}$ \\
\hline ACC & $\begin{array}{l}\text { 5'-GAGGTGGATCAGAGATTTCATAGAGA }-3^{\prime} \\
5^{\prime} \text {-AATGCGGTCCTCCTCAAACTT -3' }\end{array}$ & 1434185_at & AY451393 & $\begin{array}{l}4024-4049 \\
4104-4084\end{array}$ \\
\hline SCD1 & $\begin{array}{l}\text { 5'-TGTAAACAGCCTGTTCGTTAGCA-3' } \\
\text { 5'-CCTTAGAAACTTTCTTCCGGTCGTAA -3' }\end{array}$ & 1415964_at & BC007474.1 & $\begin{array}{c}858-880 \\
1156-1131\end{array}$ \\
\hline
\end{tabular}

FMO3, flavin monooxygenase 3; Cyt P450, cytochrome P450; CPT1, carnitine palmitoyl transferase 1; ACOX, acetyl CoA oxidase; ACC, acetyl CoA carboxylase; FAS, fatty acid synthase; ME, malic enzyme; SCD1, steoryl CoA desaturase. Hprt, hypoxanthine guanine phosphoribosyl transferase.

${ }^{*}$ For details of procedures, see pp. 59-60. 
fragmentation products was assessed using the Agilent 2100 Bioanalyzer. Fragmented, biotin-labelled cRNA (15 fg) was hybridized at $45^{\circ} \mathrm{C}$ overnight as defined in the Affymetrix 7 expression analysis protocol. The hybridization buffer contained $100 \mathrm{~mm}$-2-(4-morpholino) ethanesulfonic acid (MES), $1 \mathrm{M}-\mathrm{NaCl}, 20 \mathrm{~mm}$-EDTA, $0.01 \%$ Tween 20, four eukaryotic hybridization controls (1.5 pM-BioB; 5 pM-BioC; 25 pMBioD; $100 \mathrm{pM}$-cre), $0.1 \mathrm{mg} / \mathrm{ml}$ herring sperm DNA (Promega, Madison, WI, USA) and $0.5 \mathrm{mg} / \mathrm{ml}$ acetylated bovine serum albumin. After hybridization, the arrays were washed and stained with an Affymetrix ${ }^{\circledR}$ fluidics station following the Antibody Amplification Washing and Staining Protocol (Affymetrix Inc.). Hybridization was detected with streptavidinphycoerythrin and a confocal laser scanner (Affymetrix Inc.).

Microarray Suite 5.0 (Affymetrix Inc.) was used to determine the probe intensities and to compare expression amongst different arrays. Scaling to a target median intensity value of 125 normalized average intensity for each array. The gene expression values were $\log$ transformed (log base 2$)$. Genes were ranked on $t$ test scores, $P$-values $(P<0.05)$ and fold changes computed as actual expression values. A particular transcript was considered significantly differentially expressed between the control and CLA groups if it had a fold change $>2$, a $P$-value $<0 \cdot 05$, and this was observed in both independent experiments (described earlier). The cross-reference of the differentially expressed genes was performed using information from the Affymetrix and National Center for Biotechnology Information EntrezGene websites.

\section{Determination of flavin-containing monooxygenase activity}

Liver tissues of experimental mice were collected, frozen in liquid $\mathrm{N}$ and stored at $-80^{\circ} \mathrm{C}$ until used. The liver samples were homogenized in cold Tris/ $\mathrm{KCl}$ buffer $(0.05 \mathrm{M} / 0.15 \mathrm{M}$, $\mathrm{pH}$ 7.4), using glass/Teflon homogenizers, and microsomal fractions were purified (Chung \& Buhler, 1994). Total catalytic activities of all the liver FMO were determined by oxidation of methyl p-tolyl sulfide to methyl p-tolyl sulfoxide (Cashman \& Proudfoot, 1988). Reaction mixture contained $0.05 \mathrm{M}$-glycine buffer $(\mathrm{pH} 9.5), 50 \mu \mathrm{g}$ microsomal protein, $0.065 \mathrm{~mm}-\mathrm{NADP}+, 3.3 \mathrm{~mm}$-glucose-6-phosphate, 0.4 unit/ $\mathrm{ml}$ glucose-6-phosphate dehydrogenase, $3.3 \mathrm{mM}-\mathrm{MgCl}_{2}$ and $2.0 \mathrm{~mm}$-methyl p-tolyl sulfide in a total volume of $0.25 \mathrm{ml}$. After $10 \mathrm{~min}$ incubation at $37^{\circ} \mathrm{C}$, the reaction was stopped with $75 \mu \mathrm{l}$ acetonitrile and centrifuged $(10000 \mathrm{~g})$ for $5 \mathrm{~min}$. A $50-\mu 1$ aliquot of the supernatant was analysed with HPLC. Methyl p-tolyl sulfoxide was detected by measuring absorbance at $237 \mathrm{~nm}$ and its concentration was calculated by comparing the absorbance to a standard curve based on known concentrations. Enzyme activity is expressed as $\mathrm{p}$ mol sulfoxide/mg microsomal protein per $10 \mathrm{~min}$.

\section{Immunoprecipitation and Western blotting of flavin-containing monooxygenase 3 specific protein}

Microsomes from mice liver were passed through a Qiashredder (Qiagen) by centrifugation for $10 \mathrm{~min}$ at $20800 \mathrm{~g}$ at $4^{\circ} \mathrm{C}$. These extracts were immunoprecipitated by incubating with primary polyclonal antibody that was originally made against human FMO3 amino acid sequence position 259-279. Since the immunogenic regions of this peptide exactly matched the amino acid sequence for mouse FMO3, we used it to detect mouse FMO3. These microsome extracts $(100 \mu \mathrm{g})$ were immunoprecipitated by incubating with $2 \mu \mathrm{l}$ primary polyclonal antibody for $1 \mathrm{~h}$ at $4^{\circ} \mathrm{C}$, followed by additional 1 -h incubation with $20 \mu \mathrm{l}$ protein A/G PLUS-agarose. The pellet was collected by centrifugation at $2500 \mathrm{rpm}$ for $5 \mathrm{~min}$ at $4^{\circ} \mathrm{C}$ and washed four times with PBS. After the final wash, electrophoresis sample buffer was added and the sample was heated at $95^{\circ} \mathrm{C}$ for $2 \mathrm{~min}$. These extracts were separated by SDS polyacrylamide (10\% acrylamide) electrophoresis and transferred to nitrocellulose. The membrane was blocked with a solution of $5 \%$ powdered non-fat milk, $25 \mathrm{~mm}-$ Tris ( $\mathrm{pH} \mathrm{7.5)} \mathrm{and} 150 \mathrm{~mm}-\mathrm{NaCl}$ and then incubated with HRPconjugated goat anti-rabbit Ig-G. The bound antibody was detected using ECL chemiluminescence detection kit (Amersham, Pharmacia Biotech, Inc. Piscataway, NJ, USA).

\section{Statistical analysis}

The SAS proc glm was used for a one-way ANOVA between treatments and Levene's test was used for heterogeneity of variance (Littell et al. 2002). The two treatment means were compared with the control using Dunnett's adjustment for multiplicity. When there was evidence of heterogeneity of variance, the SAS proc mixed was used to incorporate the heterogeneity in the model. In cases for which the control data is entirely zero, $t$ tests were used to test for treatment means being significantly different from zero. Differences were considered statistically significant for $P<0 \cdot 05$.

\section{Results}

Effect of conjugated linoleic acid isomers on body, liver and liver lipid weights

Body weights of animals in the three dietary groups did not differ at the start of the study. However, at the end of feeding experimental diets body weights of the t10, c12-CLA group was significantly lower than in the other two groups (control 25.4 (SEM 0.3) g; c9, t11-CLA 26.7 (SEM 0.5) g; t10, c12CLA $23 \cdot 2$ (SEM $0 \cdot 3) \mathrm{g} ; P=0 \cdot 02$ ). Weights of the livers in animals fed the diets containing t10, c12-CLA were significantly $(P<0.05)$ greater than those in the control and c9, t11-CLA groups (mean 2.54 (SEM 0.07) g v. 1.28 (SEM 0.03) g and 1.47 (SEM 0.06) g respectively); similarly the weight of total liver lipids was approximately four times greater in the $\mathrm{t} 10$, c12-CLA than those in the control and c9, t11-CLA groups (775 (SEM 119) and 147 (SEM 18) and 175 (SEM 13) $\mathrm{mg}$ respectively).

\section{DNA microarray analysis}

Gene microarray analyses were performed to get clues regarding the genes whose expression may be altered by the dietary treatments. Fig. 1 shows an overview of the variation in hierarchical clustering of gene expression across liver tissue of mice fed diets containing c9, t11-CLA or t10, c12-CLA. The expression level of each gene (relative to its mean expression across all samples) is represented by different colours, and the colour intensities represent deviations from the mean. Mean expression is shown by the black colour, red colour indicates gene expression increased, while green 

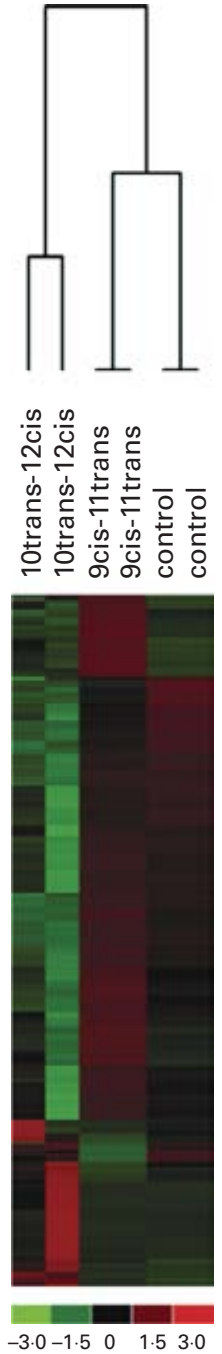

Fig. 1. Hierarchical clustering of gene expression profiles of liver tissue of mice fed diets with or without conjugated linoleic acid (CLA) isomers. Each column represents an individual mouse. Regional hierarchical clustering identified two major clusters; one representing trans 10, cis 12-CLA and the other control and cis 9, trans 11-CLA. Black colour represents the mean expression of all six animals, green represents lower expression than the mean and the red represents higher than the mean. The scale at the bottom represents 1.5 and 3 SD below and above the mean. Names of the genes altered are given online in Supplementary Table $1 \mathrm{a}-\mathrm{m})$. For details of diets and procedures, see pp. 59-61.

colour indicates gene expression decreased relative to the average. The observed pattern of gene expression identified two major clusters. The first cluster representing t10, c12CLA-fed mice and the second cluster representing the control and c9, t11-CLA-fed mice. Names of individual genes whose expression was altered by 2-fold or more are listed in the online version in Supplementary Table $1 \mathrm{a}-\mathrm{m}$.

The focus of the current paper is only on the genes involved in fatty acid metabolism; hence we performed further studies only on the genes involved in fatty acid oxidation and synthesis. Feeding a diet containing c9, t11-CLA caused a 2fold or greater change in the transcription of thirty-one hepatic genes (nine decreased and twenty-two increased) including nine genes involved in fatty acid metabolism (Supplementary Table $1 \mathrm{a}-\mathrm{m}$ and Table 3). Expression of ME was significantly
$(P<0.05)$ increased $(2 \cdot 9$-fold $)$, while change in the expression of other enzymes involved in fatty acid metabolism did not attain statistical significance.

Feeding the diet containing t10, c12-CLA caused a 2-fold or greater change in the transcription 399 genes (121 increased, 278 decreased, Supplementary Table $1 \mathrm{a}-\mathrm{m})$. This isomer significantly $(P<0.05)$ reduced the expression of FMO3 $(93 \%)$, cyt P450 (54\%), CPT1a (60\%) and PPAR $\alpha(53 \%)$ and increased the expression of $\mathrm{ME}$ by $6 \cdot 3$-fold $(P<0 \cdot 05)$. Expression of other lipogenic enzymes ACC, FAS and SCD1 increased by 3.2-, 2.6- and 1.9-folds respectively; however, these did not attain statistical significance (Table 2).

\section{Confirmation of altered gene expression by real-time PCR}

The afore-mentioned changes in the expression of fatty acid metabolism genes were confirmed by real-time PCR. Again, c9, t11-CLA diet did not alter the expression of most of the genes involved in fatty acid metabolism when compared with the control diet, with the exception of three genes. Expression of FMO3 and cyt P450 was reduced by $61 \%$ and $38 \%$ respectively, while that of SCD1 increased 5.9. fold (Table 3; $P<0.05$ for all three genes). Real-time PCR also confirmed that $\mathrm{t} 10$, c12-CLA reduced the expression of genes involved in fatty acid oxidation as indicated by the DNA microarray method (Table 3); it reduced the expression of FMO3 $95 \% \quad(P<0.0001)$, cyt P450 61\% $\quad(P=0.002)$, CPT1a $77 \%(P=0.025)$, acetyl CoA oxidase $50 \%(P=0.08)$ and PPAR $\alpha 65 \%(P=0.05)$ when compared with the corresponding values in the control group. It also increased expressions of ACC by 18 -fold $(P=0.01)$ and FAS by $3.5-$ fold $(P=0 \cdot 03)$. Expressions of SCD1 and ME were increased by greater than 2 -fold, but those did not attain statistical significance. Overall, the results from the microarray and realtime PCR data suggest that the t10, c12-CLA increased the expression of genes involved in fatty acid synthesis and reduced those of the genes involved in mitochondrial and peroxisomal $\beta$ oxidation and microsomal $\omega$ oxidation; $c 9, \mathrm{t} 11$ CLA did not alter the expression of any of these genes significantly except FMO3 $(P=0.001)$, cyt P450 $(P=0.06)$ and SCD1 $(P=0 \cdot 07)$ (Table 3$)$.

\section{Effect of conjugated linoleic acid isomers on the hepatic microsomal flavin-containing monooxygenase activity and flavin-containing monooxygenase 3 specific protein}

We determined the effect of CLA isomers on the hepatic microsomal FMO activity because 110 , c12-CLA reduced the expression of FMO3 by $95 \%$ and $\mathrm{c} 9$, t11-CLA reduced it by $61 \%$ as compared with the control group. We also determined the sum of enzymatic activity for all the hepatic isomers of FMO (FMO1, FMO3 and FMO5). Dietary c9, t11-CLA reduced the FMO activity by $15 \%$ and FMO3 specific protein by $10 \%$ (both non-significant; Fig. 2(A)(B). Diet containing t10, c12-CLA reduced the FMO activity by $40 \%$ and FMO3 protein by $67 \%(P<0.05$; Fig. 2(A)(B)). Thus, the changes caused by the two CLA isomers in total FMO activity and FMO3 specific protein and mRNA are consistent. 
Table 3. Effect of conjugated linoleic acid (CLA) isomers on the expression of genes involved in fatty acid oxidation and synthesis $\uparrow$ (Values are means with their standard errors)

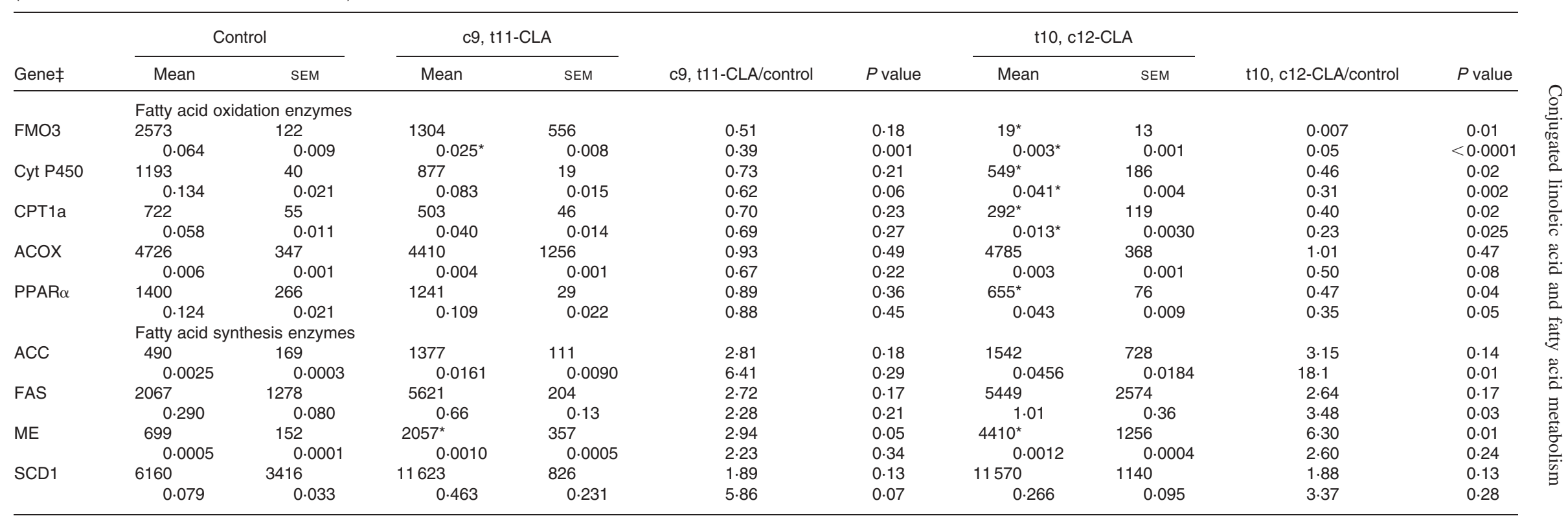

c9, t11-CLA, cis 9, trans 11-CLA; t10, c12-CLA, trans 10, cis 12-CLA; FMO3, flavin-containing monooxygenase; Cyt P450, cytochrome P450; CPT1a, carnitine palmitoyl transferase 1a; ACOX, acetyl CoA oxidase; ACC, acetyl CoA carboxylase; FAS, fatty acid synthase; ME, malic enzyme; SCD1, stearoyl CoA desaturase 1.

Mean values were significantly different from those in the control group: ${ }^{*} P<0.05 \%$.

†For details of diets and procedures, see pp. 59-60.

†The top numbers for each gene listed were determined by microarrays $(n 2)$; the bottom numbers $(n 6)$ were determined by QRT-PCR. 

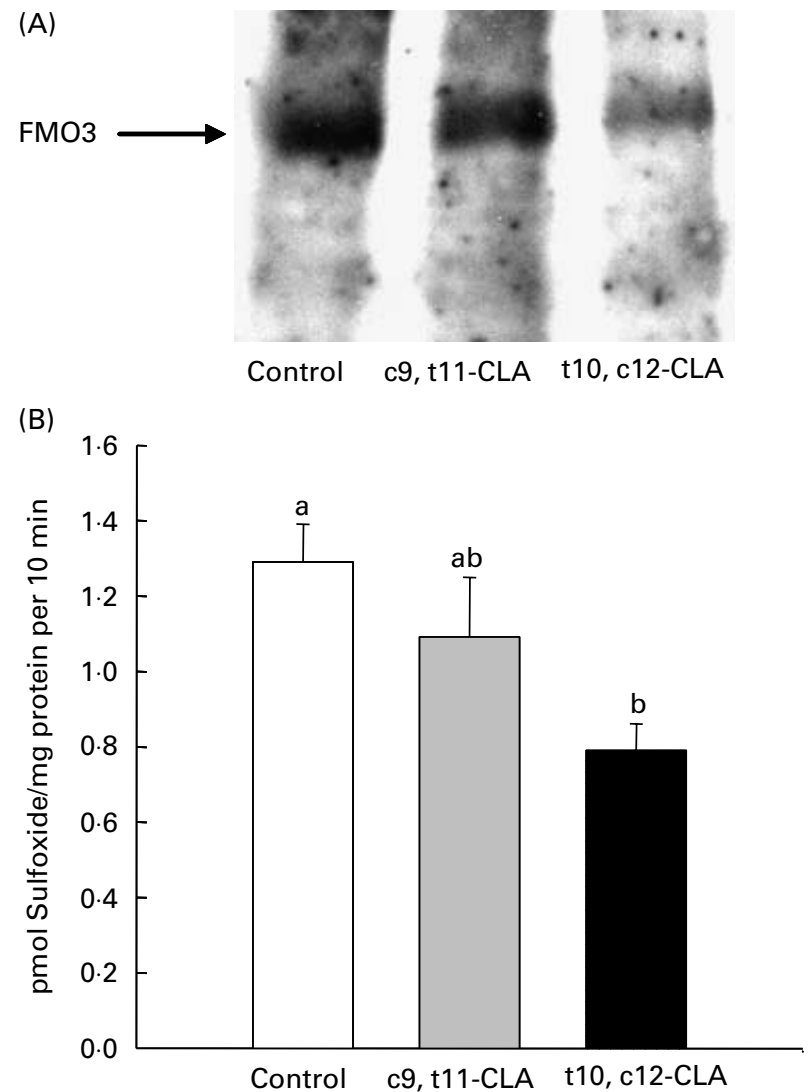

Fig. 2. Effect of dietary conjugated linoleic acid (CLA) isomers on mouse liver flavin-containing monooxygenase (FMO)-3 expression $(A)$ and $F M O$ activity (B). Data shown for FMO3 expression are representative of three experiments, while those for FMO activity are means with their standard errors represented by vertical bars $(n 3) .{ }^{a, b}$ Mean values with unlike superscript letters were significantly different $(P<0.05)$. c9, t11-CLA, cis 9 , trans 11-CLA; t10, c12-CLA, trans 10, cis 12-CLA. For details of diets and procedures, see pp. 59-61.

\section{Discussion}

We compared the effects of feeding two CLA preparations enriched in c9, t11-CLA and t10, c12-CLA isomers on the expression of hepatic enzymes involved in fatty acid metabolism. Transcription of CPT1a, FMO3, cyt P450 and PPAR $\alpha$ genes was significantly reduced by the diet containing t10, c12-CLA as determined by both the microarray and real-time PCR methods (Table 3). CPT1 is the rate limiting enzyme for mitochondrial $\beta$ oxidation, while PPAR $\alpha$ regulates $\beta$ oxidation in mitochondria and peroxisomes; cyt P450 and FMO3 are involved in the $\omega$ oxidation and drug detoxification in the microsomes. Expression of acetyl CoA oxidase, the rate limiting enzyme for peroxisomal fatty acid oxidation, was reduced by $50 \%$ by the diet containing t10, c12-CLA, although it was not statistically significant $(P=0.08$; Table 3$)$. The reduced expression of these five genes suggests that $\mathrm{t} 10$, c12-CLA may reduce fatty acid oxidation in the mitochondria, peroxisomes and the microsomes. Thus, reduced fatty oxidation in all these three organelles may contribute to the development of fatty liver in mice fed diets containing t10, c12-CLA. This diet also increased the expression of four lipogenic genes (ACC, FAS, ME and SCD1) by more than 2-fold; however, statistical significance was attained only for the expressions of ACC and FAS
$(P<0.05$; Table 3$)$. Neither of the CLA isomers significantly altered the expression of nuclear factors, liver $\mathrm{X}$ receptor $\alpha$ and regulatory element-binding protein- $1 \mathrm{c}$, that regulate fatty acid synthesis (Supplementary Table 1a-m). We cannot determine the specific contributions of reduced fatty acid oxidation and increased fatty acid synthesis to the development of fatty liver in animals fed a diet containing t10, c12-CLA, but it appears that both reduced fatty acid oxidation and increased fatty acid synthesis may contribute to the development of fatty liver. Other factors such as reduced transport of lipids from liver may also contribute to the development of the fatty liver; results from a published report (Poirier et al. 2005) and our own microarray data do not support this notion. Dietary c9, t11-CLA increased the liver lipid by only $15 \%$, which was not statistically significant. It did not reduce the expression of CPT1, acetyl CoA oxidase and PPAR $\alpha$ genes and caused modest reductions in the expressions of FMO3 and cyt P450. These results suggest that $\mathrm{c} 9$, $\mathrm{t} 11-\mathrm{CLA}$ did not reduce the mitochondrial and peroxisomal fatty acid oxidation. The present study protocol cannot distinguish if the reductions in the expression of FMO3 and cyt P450 caused by c9, t11-CLA are specific to this isomer or because of its contamination with t10, c12-CLA. Completely pure CLA isomer preparations are needed to address this issue.

The present results showing down regulation of the genes involved in fatty acid oxidation by the t10, c12-CLA are at variance with those showing an increased expression of the CPT1a in mice fed a mixture of CLA isomers (Takahashi et al. 2003; Javadi et al. 2004; Ide, 2005) or a purified t10, c12-CLA isomer (Degrace et al. 2004). We are not sure of the reasons for this discrepancy, but the design and methods used were considerably different between the present and other studies. We used female mice and fully quantitative real-time RT-PCR techniques, while those investigators used male mice and semi-quantitative RT-PCR methods. Furthermore, it is inappropriate to compare our results with those obtained with a mixture of CLA isomers (Takahashi et al. 2003; Javadi et al. 2004; Ide, 2005), since the two isomers have contrasting effects on fatty acid metabolism (Roche et al. 2003; Kelley et al. 2004). The amount of CLA and the duration of its feeding were also different between the present and other studies. Most significantly, the basal diet in these studies with a mixture of CLA isomers was a high-fat diet (total fat 15-19 weight \%) rich in SFA (palm oil in Takahashi et al. 2003; Ide, 2005) or SFA and MUFA (coconut, olive, palm and high oleic sunflower oils in Javadi et al. 2004). In the present study, maize oil (5 weight \%) was the source of fat and $0.5 \%$ CLA was incorporated by replacing an equivalent amount of the maize oil. It is possible that CLA may increase hepatic fatty acid oxidation when fed with high-fat diets that are rich in SFA or MUFA, since the amount and type of dietary fatty acids regulate the expression of hepatic genes and the development of non-alcoholic steatosis and steatohepatitis (Demizieux et al. 2002). In the study with the purified t10, c12-CLA, the basal diet contained sunflower and linseed oils and 1 weight \% oleic acid or CLA were added to the control and test diets, respectively (Degrace et al. 2004). In this study both the in vitro CPT1 activity and mRNA expression were significantly increased by t10, c12-CLA. Also increased were the liver malonyl CoA that inhibits CPT1 and the sensitivity of CPTI to malonyl CoA 
(50\% inhibition, 2 v. $12 \mu \mathrm{mol} / \mathrm{l}$ ). These authors recognize the inconsistency between their results and propose that in vivo hepatic fatty acid oxidation may actually be suppressed by this isomer. We found reduction in mRNA not only for CPT1, but also for four other genes involved in fatty acid oxidation. The present results are consistent with the proposal put forward by the investigators, which was discussed earlier (Degrace et al. 2004), the in vitro reduction of fatty acid oxidation by isolated mitochondria treated with CLA (Clarke, 2001) and the development of fatty liver observed in many studies with CLA. Increased expression of the lipogenic genes, ACC, FAS, ME and SCD1, found in the present study are consistent with those of published reports (Takahashi et al. 2003; Degrace et al. 2004; Javadi et al. 2004; Ide, 2005).

The most dramatic effect of t10, c12-CLA in the present study was the down regulation of the genes for cyt P450 and FMO3, which are involved in the $\omega$ hydroxylation of the fatty acids and the production of dicarboxylic fatty acids (White et al. 1978; Krueger \& Williams, 2005; Sanders et al. 2005; Weng et al. 2005). Once formed, dicarboxylic fatty acids can be shortened from either end of the molecule by $\beta$ oxidation. This pathway plays a significant role in overall fatty acid oxidation during starvation and diabetes (Orellana et al. 1998). It may play a significant role in the overall hepatic fatty acid oxidation in mice fed diet containing t10, c12CLA, since these animals do develop symptoms of diabetes (Poirier et al. 2005). This interpretation is also consistent with a recent finding that mice deleted of the cyt P450 gene develop a fatty liver (Weng et al. 2005). In addition to their role in fatty acid metabolism, both these enzymes detoxify numerous foreign compounds and also limit the length of time during which different drugs may be effective (Krueger et al. 2006). Thus, the suppression of these detoxifying enzyme systems may have additional health risks in addition to the development of fatty liver. FMO3 is the major hepatic isomer in man and a mutation in this gene causes trimethyaminuria, a condition wherein individuals excrete trimethylamine rather than trimethylamine oxide; trimethylamine produces a fishy odour in urine, sweat, breath and other bodily excretions (Seibel \& Walsh, 2002). It is difficult to extrapolate the results of this and many other mice studies to man because the amount of CLA used in most of the mice studies is equivalent to $30-60 \mathrm{~g} / 60 \mathrm{~kg}$ person per d (Kelley \& Erickson, 2003); however, the long-term consumption of even lesser amounts of t10, c12-CLA by man may have serious health consequences.

In summary, the results of the present study indicate that the development of the fatty liver in mice fed diets containing $t 10$, c12-CLA may be due both to reduced fatty acid oxidation and increased fatty acid synthesis. Results in addition to FMO3 need to be confirmed at the level of enzyme specific proteins and activities. To the best of our knowledge this is the first in vivo report that shows reduced expression of fatty acid oxidation and drug detoxification genes by t10, c12-CLA. Further studies are needed to determine the health consequences of the reduced expression of these genes by t10, c12-CLA.

\section{Note}

Supplementary information accompanies this paper on the journal's website (http://www.nutritionsociety.org).

\section{Acknowledgements}

We are most appreciative of the help provided by Terry Neidlinger in the HPLC analysis of FMO activity, Dr Colin Baron with the analysis of the microarray data and Dr John Newman in the preparation of tables and figures.

\section{References}

Belury MA (2002) Dietary conjugated linoleic acid in health: physiological effects and mechanisms of action. Ann Rev Nutr 22, 505-531.

Belury MA \& Kempa-Steczko A (1997) Conjugated linoleic acid modulates hepatic lipid composition in mice. Lipids 32, 199-204.

Cashman JR \& Proudfoot J (1988) A reverse-phase liquid chromatographic assay for flavin-containing monooxygenase activity. Analytical Biochemistry 175, 274-280.

Chung WG \& Buhler DR (1994) The effect of spironolactone treatment on the cytochrome P450-mediated metabolism of the pyrrolizidine alkaloid senecionine by hepatic microsomes from rats and guinea pigs. Toxicology and Applied Pharmacology 127, 314-319.

Clarke S (2001) Nonalcoholic steatosis and steatohepatitis. 1. Molecular mechanisms for polyunsaturated fatty acid regulation of gene transcription. Am J Physiol Gastrointest Liver Physiol 281, G865-G869.

Clement L, Poirer H \& Noit I (2002) Dietary trans-10, cis-12 conjugated linoleic acid induces hyperinsulinemia and fatty liver in mouse. J. Lipid Res 43, 1400-1409.

Degrace P, Demizieux L \& Gresti J (2003) Association of liver steatosis with lipid oversecretion and hypotriglyceridaemia in C57BL/6J mice fed trans-10, cis-12 linoleic acid. FEBS Letters 546, 335-339.

Degrace P, Demizieux L, Gresti J, Chardigny JM, Sebedio JL \& Clouet P (2004) Hepatic steattosis is not due to impaired fatty acid oxidation capacities in C57BL/6J mice fed the conjugated trans-10, cis-12-isomer of linoleic acid. J. Nutr 134, 861-867.

Demizieux L, Degrace P \& Gresti J (2002) Conjugated linoleic acid isomers in mitochondria: evidence for an alteration of fatty acid oxidation. J. Lipid Res 43, 2112-2122.

Eulitz K, Yurawecz MP, Sehat N, Fritsche J, Roach JAG, Mossoba MM, Kramer JKG, Adlof RO \& Ku Y (1999) Preparation, separation, and confirmation of the eight geometrical cis/ trans conjugated linoleic acid isomers, 8,10 through 11, 13-18:2. Lipids 34, 873-877.

Falls JG, Cherrington NJ \& Clements KM (1997) Molecular cloning, sequencing, and expression of Escherichia coli of mouse flavincontaining monooxygenase 3 (FMO3): comparison with human isoform. Achieves of Biochemistry and Biophysics 347, 9-18.

Ide $T$ (2005) Interaction of fish oil and conjugated linoleic acid in affecting hepatic activity of lipogenic enzymes and gene expression in liver and adipose tissue. Diabetes 54, 412-423.

Javadi M, Beynen AC \& Hovenier R (2004) Prolonged feeding of mice with conjugated linoleic acid increases hepatic fatty acid synthesis relative to oxidation. Journal of Nutritional Biochemistry 15, 680-687.

Kelley DS, Bartolini G, Warren JM, Simon VA, Erickson KL \& Mackey BE (2004) Contrasting effects of t10,c12- and c9,t11-conjugated linoleic acid isomers on the fatty acid profiles of mouse liver lipids. Lipids 39, 135-141.

Kelley DS \& Erickson KL (2003) Modulation of body composition and immune cell functions by conjugated linoleic acid in humans and animal models: benefits vs. risks. Lipids 4, 377-386.

Krueger SK, Vandyke JE, Williams DE \& Hines RN (2006) The role of flavin-containing monooxygenase (FMO) in the metabolism of tamoxifen and other tertiary amines. Drug Metab Rev 38, 139-147.

Krueger SK \& Williams DE (2005) Mammalian flavin-containing monooxygenases:structure/function, genetic polymorphisms and role in drug metabolism. Pharmacology and Therapeutics 106, 357-387. 
R. Rasooly et al.

Littell RC, Stroup WW \& Freund RJ (2002) SAS for Linear Models, 4th ed. Cary, NC: SAS Institute Inc.

McGuire MK, McGuire MA, Ritzenthaler K \& Scultz TD (1999) Dietary sources and intakes of conjugated linoleic acid in humans. In Advances in Conjugated Linoleic Acid, 1, pp. 369-376 [MP Yurawecz et al., editors]. Champaign, IL: AOCS Press.

Orellana M, Rodrigo R \& Valdes E (1998) Peroxisomal and microsomal fatty acid oxidation in liver of rats after chronic ethanol consumption. Gen Pharmac 31, 817-820.

Park Y, Storkson JM, Albright KJ, Liu W \& Pariza MW (1999) Evidence that trans-10, cis-12 isomer of conjugated linoleic acid induces body composition changes in mice. Lipids 34, 235-241.

Poirier H, Rouault C \& Clement L (2005) Hyperinsulinaemia triggered by dietary conjugated linoleic acid is associated with decrease in leptin and adiponectin plasma levels and pancreatic beta cell hyperplasia in the mouse. Diabetologia 48, 1059-1065.

Reddy JK \& Hashimoto T (2001) Peroxisomal b-oxidation and peroxisome proliferator-activated receptor a: an adaptive metabolic system. Ann Rev Nutr 21, 193-230.

Roche HM, Noone E \& Sewter CC (2003) Isomer-dependent metabolic effects of conjugated linoleic acid: insights from molecular markers sterol regulatory element-binding protein-1c and LXR $\alpha$. Diabetes 188, 1798-1799.

Sanders RJ, Ofman R, Valianpour F, Kemp S \& Wanders RJ (2005) Evidence of two enzymatic pathways for $\omega$-oxidation of docosanoic acid in rat liver microsomes. J Lipid Res 46, 1001-1008.
Seibel BA \& Walsh PJ (2002) Trimethylamine oxide accumulation in marine animals: relationship to acylglycerol storage. Journal Experimental Biology 205, 297-306.

Takahashi Y, Kushiro M, Shinohara K \& Ide T (2003) Activity and mRNA levels of enzymes involved in fatty acid synthesis and oxidation in mice fed conjugated linoleic acid. Biochim Biophys Acta 163, 265-273.

Tricon S, Burdge GC, Williams CM, Calder PC \& Yaqoob P (2005) The effects of conjugated linoleic acid on human health-related outcomes. Proc Nutr Soc 64, 171-182.

Tsuboyama-Kasaoka N, Takahashi M, Tanemura K, Kim HJ, Tange T, Okuyama H, Kasai M, Shinji I \& Ezaki O (2000) Conjugated linoleic acid supplementation reduces adipose tissue by apoptosis and develops lipodystrophy in mice. Diabetes 49 , $1534-1542$.

Warren JM, Simon VA, Bartolini G, Erickson KL, Mackey BE \& Kelley DS (2003) Trans-10, cis-12 CLA increases liver and decreases adipose tissue lipids in mice: Possible role of specific lipid metabolism genes. Lipids 38, 497-504.

Weng Y, DiRusso CC, Reilly AA, Blacks PN \& Ding X (2005) Hepatic gene expression changes in mouse models with liver-specific deletion or global suppression of the NADPH-cytochrome P450 reductase gene. J Biol Chem 280, 31686-31698.

White A, Handler P, Smith EL, Hill RL \& Lehman IR (editors) (1978) Lipid metabolism. In Principles of Biochemistry. 6th edn., pp. 569-606. New York: McGraw Hill Book Company. 
Supplementary Table 1a. Effect of CLA isomers on mouse liver gene expression

\begin{tabular}{|c|c|c|c|c|c|c|c|c|}
\hline \multirow[b]{2}{*}{ Gene name } & \multirow[b]{2}{*}{ probe set (Affimetx) } & \multirow[b]{2}{*}{ Accession \# } & \multirow[b]{2}{*}{ Biological function/Process } & \multirow{2}{*}{$\begin{array}{l}\text { Control } \\
\text { Mean }^{a}\end{array}$} & \multicolumn{2}{|c|}{ t10-,c12-CLA } & \multicolumn{2}{|c|}{ c9-,t11CLA } \\
\hline & & & & & Mean $^{a}$ & $\%$ Control & Mean $^{a}$ & $\%$ Control \\
\hline Jun-B oncogene & 1415899_at & NM_008416 & Regulation of transcription & 259 & $99 \cdot 9$ & $38.5 \%$ & 134 & $51.5 \%$ \\
\hline Thioredoxin interacting protein & 1415997_at & AF173681 & Response to oxidative stress & 241 & $99 \cdot 0$ & $41 \cdot 1 \%$ & 282 & $117 \%$ \\
\hline Scavenger receptor class B, member 1 & 1416050_a_at & NM_016741 & Cell adhesion & 1610 & 584 & $36 \cdot 3 \%$ & 1030 & $64.0 \%$ \\
\hline FK506 binding protein 5 & 1416125_at & U16959 & Protein folding & 474 & 213 & $44.8 \%$ & 403 & $85.0 \%$ \\
\hline Serine (or cysteine) proteinase inhibitor & 1416318_at & AF426024 & Regulation of protein catabolism & 241 & $29 \cdot 1$ & $12 \cdot 1 \%$ & 137 & $57 \cdot 1 \%$ \\
\hline Calcium binding protein, intestinal & 1416497_at & J05186 & Electron transport & 1400 & 630 & $44.9 \%$ & 886 & $63 \cdot 2 \%$ \\
\hline Plexin B2 & 1416683_at & NM_138749 & Positive regulation of axonogenesis & 943 & 439 & $46.6 \%$ & 775 & $82.2 \%$ \\
\hline Kidney expressed gene 1 & 1416833_at & NM_029550 & -- & 1120 & 456 & $40.7 \%$ & 927 & $82.7 \%$ \\
\hline Lymphocyte antigen 6 complex, locus D & 1416930_at & NM_010742 & Defense response & 88.5 & 528 & $597 \%$ & $93 \cdot 6$ & $106 \%$ \\
\hline P450 (cytochrome) oxidoreductase & 1416933_at & NM_008898 & Electron transport & 1460 & 501 & $34.4 \%$ & 1040 & $71.5 \%$ \\
\hline Angiopoietin-like 4 & 1417130_s_at & NM_020581 & Negative regulation of apoptosis & 1030 & 433 & $41.9 \%$ & 737 & $71.4 \%$ \\
\hline EH-domain containing 3 & 1417235_at & BM23̈3419 & - & 957 & 459 & $48.0 \%$ & 946 & $98.9 \%$ \\
\hline Olfactory receptor 56 & 1417292_at & NM_008330 & Defense response & 764 & 370 & $48.4 \%$ & 618 & $80.9 \%$ \\
\hline Sphingosine kinase 2 & 1417431_a_at & AF245448 & Protein kinase $\mathrm{C}$ activation & 252 & $90 \cdot 1$ & $35.8 \%$ & 195 & $77.6 \%$ \\
\hline Actin dependent regulator of chromatin & 1417440_at & NM_033566 & Maintenance of chromatin architecture & 571 & 276 & $48.4 \%$ & 519 & $90.9 \%$ \\
\hline Serine (or cysteine) proteinase inhibitor, & 1417498_at & NM_008878 & Acute-phase response & 5390 & 2510 & $46.7 \%$ & 4770 & $88.5 \%$ \\
\hline RIKEN cDNA 1300003D03 gene & 1417566_at & AK007421 & Lipid metabolism & 158 & 328 & $208 \%$ & 267 & $169 \%$ \\
\hline Expressed sequence Al481100 & 1417793_at & NM_019440 & - & 466 & 220 & $47.3 \%$ & 413 & $88.7 \%$ \\
\hline Murinoglobulin 1 & 1417835_at & NM_008645 & Transporter activity & 4920 & 2150 & $43.6 \%$ & 3180 & $64.6 \%$ \\
\hline Glycosylphosphatidylinositol phospholipase D1 & 1418050_at & NM_008156 & Cell-matrix adhesion & 1950 & 896 & $46.1 \%$ & 1470 & $75 \cdot 6 \%$ \\
\hline Neurogenic differentiation 4 & 1418055_at & NM_007501 & Regulation of transcription & 225 & 31.5 & $14.0 \%$ & 233 & $104 \%$ \\
\hline Arginine vasopressin receptor $1 \mathrm{~A}$ & 1418603_at & D49729 & Signal transduction & 373 & 151 & $40.5 \%$ & 345 & $92.4 \%$ \\
\hline Histidine ammonia lyase & 1418645_at & L07645 & Histidine metabolism & 2140 & 913 & $42 \cdot 6 \%$ & 2200 & $103 \%$ \\
\hline Cytochrome P450, family 2, & 1418653_at & NM_134144 & Electron transport & 5020 & 2390 & $47.7 \%$ & 3410 & $68.0 \%$ \\
\hline Solute carrier family 38, member 3 & 1418706_at & NM_023805 & Ion transport & 5020 & 2450 & $48.9 \%$ & 5000 & $100 \%$ \\
\hline CD2 antigen & 1418770_at & NM_013486 & Cell adhesion & $52 \cdot 3$ & 158 & $302 \%$ & 135 & $258 \%$ \\
\hline Alanine-glyoxylate aminotransferase & 1418833_at & NM_016702 & Metabolism & 3090 & 1090 & $35.3 \%$ & 2650 & $85.9 \%$ \\
\hline Pleckstrin homology-like domain & 1418835_at & NM_009344 & FasL biosynthesis & 1840 & 550 & $29.9 \%$ & 1060 & $57.8 \%$ \\
\hline RIKEN cDNA 1200011D03 gene & 1418858_at & NM_023617 & Electron transport & 1180 & 499 & $42.4 \%$ & 720 & $61 \cdot 2 \%$ \\
\hline Annexin A2 & 1419091_a_at & NM_007585 & Angiogenesis / fibrinolysis & 234 & 511 & $218 \%$ & 301 & $128 \%$ \\
\hline Cytochrome P450, family 2. subfamily c, & 1419094_at & NM_010001 & Electron transport & 6250 & 3030 & $48.5 \%$ & 4990 & $79.9 \%$ \\
\hline $\mathrm{N}$-acetyltransferase 6 & 1419213_at & NM_019750 & Cell cycle & 649 & 317 & $48.9 \%$ & 546 & $84.0 \%$ \\
\hline Serum amyloid A 4 & 1419318_at & NM_011316 & Acute-phase response & 1460 & 460 & $31.4 \%$ & 1000 & $68.4 \%$ \\
\hline
\end{tabular}

${ }^{\text {a } A l l ~ m e a n s ~ a r e ~ f r o m ~} 2$ animals per group. 
Supplementary Table 1b. Effect of CLA isomers on mouse liver gene expression

\begin{tabular}{|c|c|c|c|c|c|c|c|c|}
\hline \multirow[b]{2}{*}{ Gene name } & \multirow[b]{2}{*}{ probe set (Affimetx) } & \multirow[b]{2}{*}{ Accession \# } & \multirow[b]{2}{*}{ Biological function/Process } & \multirow{2}{*}{$\begin{array}{l}\text { Control } \\
\text { Mean }^{\mathrm{a}}\end{array}$} & \multicolumn{2}{|c|}{ t10-,c12-CLA } & \multicolumn{2}{|c|}{ c9-,t11CLA } \\
\hline & & & & & Mean $^{a}$ & $\%$ Control & Mean $^{a}$ & $\%$ Control \\
\hline Serum amyloid $A 4$ & 1419319_at & NM_011316 & Acute-phase response & 389 & 115 & $29.6 \%$ & 321 & $82.5 \%$ \\
\hline Diacylglycerol O-acyltransferase 2-like 1 & 1419504_at & NM_026713 & Diacylglycerol biosynthesis & $25 \cdot 5$ & 177 & $694 \%$ & $42 \cdot 3$ & $166 \%$ \\
\hline Lipase, hepatic & 1419560_at & NM_008280 & Lipid metabolism & 1760 & 716 & $40.8 \%$ & 1230 & $70 \cdot 1 \%$ \\
\hline Lectin, galactose binding, soluble 1 & 1419573_a_at & NM_008495 & Myoblast differentiation & 407 & 1600 & $394 \%$ & 651 & $160 \%$ \\
\hline Nuclear protein 1 & 1419665_a_at & NM_019738 & - & $69 \cdot 3$ & 175 & $253 \%$ & $90 \cdot 0$ & $130 \%$ \\
\hline RIKEN cDNA 5630401H01 gene & 1419683_at & BB400773 & Amino acid phosphorylation & 177 & 1060 & $598 \%$ & 353 & $199 \%$ \\
\hline RIKEN cDNA $1700029 F 12$ gene & 1419715_at & NM_025585 & - & 328 & 116 & $35.5 \%$ & 273 & $83.5 \%$ \\
\hline Similar to plectin (LOC381012), mRNA & 1419835_s_at & AW123286 & - & 503 & 232 & $46.0 \%$ & 461 & $91.7 \%$ \\
\hline Spinocerebellar ataxia 2 homolog (human) & 1419866_s_at & AW544490 & - & 391 & 178 & $45.5 \%$ & 329 & $84.1 \%$ \\
\hline MOUSE TYROSINE-PROTEIN KINASE JAK3 & 1420310_at & BG083989 & & 3.65 & 286 & $7850 \%$ & 3.99 & $109 \%$ \\
\hline Organic anion transporter family, member $1 \mathrm{a} 1$ & 1420379_at & AB031813 & Ion transport & 266 & 108 & $40 \cdot 6 \%$ & 150 & $56.4 \%$ \\
\hline Organic anion transporter family, member $1 \mathrm{a} 4$ & 1420405_at & NM_030687 & Ion transport & 1160 & 518 & $44.7 \%$ & 709 & $61 \cdot 1 \%$ \\
\hline Nucleosome assembly protein 1 -like 1 & 1420479_a_at & BG064031 & Nucleosome assembly & 148 & 372 & $252 \%$ & 265 & $180 \%$ \\
\hline Neuronal d4 domain family member & 1420529_at & AW553317 & Regulation of transcription & $35 \cdot 0$ & 146 & $417 \%$ & 34.3 & $97.9 \%$ \\
\hline Retinal dehydrogenase 6 & 1420541_at & NM_009040 & Metabolism & 608 & 1230 & $202 \%$ & 1070 & $176 \%$ \\
\hline ATP-binding cassette, sub-family G, member 8 & 1420656_at & AF324495 & Transport & 805 & 382 & $47.5 \%$ & 633 & $78 \cdot 7 \%$ \\
\hline C-type lectin, superfamily member 12 & 1420699_at & NM_020008 & Phagocytosis/ signal transduction & 211 & 548 & $259 \%$ & 168 & $79.6 \%$ \\
\hline RIKEN cDNA 4933433D23 gene & 1420836_at & BB032012 & Transport & 1260 & 494 & $39.2 \%$ & 953 & $75.6 \%$ \\
\hline Protein tyrosine phosphatase, receptor type, F & 1420841_at & BF235516 & Amino acid dephosphorylation & 891 & 412 & $46 \cdot 2 \%$ & 693 & $77 \cdot 7 \%$ \\
\hline Protein tyrosine phosphatase, receptor type, $\mathrm{F}$ & 1420843_at & BF235516 & Amino acid dephosphorylation & 2420 & 1080 & $44.9 \%$ & 1980 & $82.0 \%$ \\
\hline Glutathione S-transferase, alpha 2 (Yc2) & 1421040_a_at & NM_008182 & Transferase activity & $90 \cdot 1$ & 321 & $356 \%$ & 130 & $145 \%$ \\
\hline Glutathione S-transferase, alpha 2 (Yc2) & 1421041_s_at & NM_008182 & Glutathione metabolism & 150 & 519 & $347 \%$ & 192 & $129 \%$ \\
\hline Cytochrome P450, family 7 , subfamily b & 1421074_at & NM_007825 & Lipid metabolism & 637 & 256 & $40.3 \%$ & 379 & $59.6 \%$ \\
\hline ATP-binding cassette, sub-family C, member 6 & 1421212_at & NM_018795 & Transport & 867 & 400 & $46.2 \%$ & 755 & $87.1 \%$ \\
\hline $\mathrm{cmp}-\mathrm{N}$-acetylneuraminic acidhydroxylase & 1421214_at & NM_007717 & Electron transport & 231 & 557 & $241 \%$ & 342 & $148 \%$ \\
\hline Solute carrier family 6 , member 6 & 1421346_a_at & NM_009320 & Beta-alanine transport & 534 & 247 & $46 \cdot 2 \%$ & 442 & $82.7 \%$ \\
\hline Prolactin receptor & 1421382_at & NM_008932 & Regulation of cell adhesion & 1220 & 601 & $49.1 \%$ & 1320 & $108 \%$ \\
\hline RAD51-like 1 (S. cerevisiae) & 1421430_at & NM_009014 & DNA repair & 108 & 324 & $301 \%$ & 182 & $169 \%$ \\
\hline RIKEN cDNA 5730402K07 gene & 1421622_a_at & NM_019688 & Protein amino acid phosphorylation & 312 & 124 & $39.9 \%$ & 250 & $80 \cdot 1 \%$ \\
\hline Cyclin-dependent kinase 8 & 1421741_at & NM_007820 & Electron transport & 443 & 182 & $41.2 \%$ & 472 & $107 \%$ \\
\hline Mitochondrial ribosomal protein L19 & 1421913_at & BB0 41267 & Protein biosynthesis & 39.4 & 162 & $411 \%$ & 86.9 & $220 \%$ \\
\hline Basic transcription element binding protein 1 & 1422264_s_at & NM_010638 & Regulation of transcription & 383 & 156 & $40.7 \%$ & 271 & $70 \cdot 8 \%$ \\
\hline
\end{tabular}

${ }^{a}$ All means are from 2 animals per group. 
Supplementary Table 1c. Effect of CLA isomers on mouse liver gene expression

\begin{tabular}{|c|c|c|c|c|c|c|c|c|}
\hline \multirow[b]{2}{*}{ Gene name } & \multirow[b]{2}{*}{ probe set (Affimetx) } & \multirow[b]{2}{*}{ Accession \# } & \multirow[b]{2}{*}{ Biological function/Process } & \multirow{2}{*}{$\begin{array}{l}\text { Control } \\
\text { Mean }^{\mathrm{a}}\end{array}$} & \multicolumn{2}{|c|}{$\mathrm{t} 10-, \mathrm{c} 12-\mathrm{CLA}$} & \multicolumn{2}{|c|}{ c9-,t11CLA } \\
\hline & & & & & Mean $^{a}$ & $\%$ Control & Mean $^{\mathrm{a}}$ & \% Control \\
\hline Cdk5 and Abl enzyme substrate 1 & 1422477_at & AF328140 & Regulation of cell cycle & 220 & 102 & $46.5 \%$ & 150 & $68.2 \%$ \\
\hline Metallothionein 1 & 1422557_s_at & NM_013602 & Metal ion homeostasis & 2140 & 883 & $41.3 \%$ & 1570 & $73.4 \%$ \\
\hline Solute carrier family 7 , member 2 & 1422648_at & BF533509 & Amino acid transport & 430 & 182 & $42.4 \%$ & 248 & $57 \cdot 8 \%$ \\
\hline Forkhead box Q1 & 1422735_at & NM_008239 & Regulation of transcription & 366 & 170 & $46.4 \%$ & 259 & $70 \cdot 8 \%$ \\
\hline Insulin-like growth factor binding protein & 1422826_at & NM_008340 & Cell adhesion & 1310 & 405 & $31.0 \%$ & 1170 & $89.5 \%$ \\
\hline SMC6 structural maintenance of chromosomes 6 & 1422910_s_at & AU022584 & - & $29 \cdot 9$ & 133 & $445 \%$ & 95 & $317 \%$ \\
\hline Peroxisomal acyl-CoA thioesterase $2 \mathrm{~A}$ & 1422925_s_at & NM_134246 & Acyl-CoA metabolism & 946 & 357 & $37.7 \%$ & 1380 & $146 \%$ \\
\hline Methyltransferase-like 3 & 1423099_a_at & AW556332 & RNA methylation & 403 & 149 & $36.8 \%$ & 214 & $53.1 \%$ \\
\hline CD36 antigen & 1423166_at & BB534670 & Cell adhesion & 697 & 1470 & $210 \%$ & 842 & $121 \%$ \\
\hline Natural killer tumor recognition sequence & 1423249_at & BB317504 & Protein folding & $21 \cdot 1$ & 122 & $578 \%$ & 106 & $501 \%$ \\
\hline Hepatoma-derived growth factor, related protein 3 & 1423252_at & BB291880 & Cell proliferation & $98 \cdot 3$ & 202 & $205 \%$ & 102 & $104 \%$ \\
\hline Frizzled homolog 8 (Drosophila) & 1423348_at & AV345166 & Signal transduction & 202 & 40.1 & $19 \cdot 8 \%$ & 149 & $73.8 \%$ \\
\hline Phosphoenolpyruvate carboxykinase 1 , cytosolic & 1423439_at & AW106963 & Gluconeogenesis / lipid metabolism & 4390 & 1690 & $38.5 \%$ & 3080 & $70 \cdot 2 \%$ \\
\hline Serine (or cysteine) proteinase inhibitor & 1423867_at & BF234005 & Endopeptidase inhibitor & 318 & 129 & $40 \cdot 6 \%$ & 167 & $52.4 \%$ \\
\hline Peroxisomal biogenesis factor 6 & 1424078_s_at & ВС003424 & Protein binding & 612 & 283 & $46.2 \%$ & 566 & $92.5 \%$ \\
\hline HECT domain containing 1 & 1424141_at & BC010205 & Protein binding & 1050 & 508 & $48.5 \%$ & 820 & $78.3 \%$ \\
\hline Thyrotroph embryonic factor & 1424175_at & BC017689 & Regulation of transcription & 403 & 201 & $49.9 \%$ & 202 & $50 \cdot 1 \%$ \\
\hline Carboxylesterase 2 & 1424245_at & BC015290 & Hydrolase activity & 204 & 528 & $259 \%$ & 331 & $162 \%$ \\
\hline RIKEN cDNA 1600023 A02 gene & 1424351_at & AF334269 & Endopeptidase inhibitor & 224 & 695 & $310 \%$ & 303 & $135 \%$ \\
\hline LIM and senescent cell antigen like domains 2 & 1424408_at & BC010816 & Metal ion binding & 705 & 342 & $48.5 \%$ & 514 & $72.9 \%$ \\
\hline cDNA sequence BC011468 & 1424544_at & BC012437 & Metal ion binding & 271 & 131 & $48.4 \%$ & 208 & $76 \cdot 8 \%$ \\
\hline cDNA sequence $\mathrm{BC} 034834$ & 1424576_s_at & BC025819 & Monooxygenase activity & 2340 & 600 & $25.7 \%$ & 1670 & $71.4 \%$ \\
\hline RIKEN cDNA 4432417N03 gene & 1424585_at & BC024698 & - & 365 & 159 & $43.6 \%$ & 304 & $83.5 \%$ \\
\hline RIKEN cDNA 2700053 F16 gene & 1424650_at & BC009151 & Electron transport & 531 & 240 & $45.2 \%$ & 374 & $70.5 \%$ \\
\hline Laminin, alpha 4 & 1424807_at & BB053010 & Blood vessel development & 109 & 246 & $226 \%$ & 126 & $116 \%$ \\
\hline RIKEN cDNA A330049M08 gene & 1424838_at & BC005730 & - & 171 & 69.7 & $40 \cdot 8 \%$ & 136 & $79.4 \%$ \\
\hline Bromodomain containing 4 & 1424922_a_at & BC008532 & - & 310 & 147 & $47.4 \%$ & 309 & $100 \%$ \\
\hline Epidermal growth factor receptor & 1424932_at & U03425 & Signal transduction & 597 & 162 & $27 \cdot 1 \%$ & 347 & $58.1 \%$ \\
\hline RIKEN cDNA C730032N17 gene & 1425034_at & BC018306 & Transport & 641 & 311 & $48.5 \%$ & 370 & $57.7 \%$ \\
\hline RIKEN cDNA 2610034N03 gene & 1425050_at & AK010892 & Metabolism & 226 & 463 & $205 \%$ & 422 & $187 \%$ \\
\hline Sodium channel, type I, alpha polypeptide & 1425088_at & AF112185 & Ion transport & 265 & 113 & $42.5 \%$ & 218 & $82.1 \%$ \\
\hline Leukemia inhibitory factor receptor & 1425107_a_at & D17444 & Cytokine receptor activity & 1830 & 534 & $29 \cdot 2 \%$ & 1060 & $57.7 \%$ \\
\hline Colony stimulating factor 1 (macrophage) & 1425154_a_at & M21149 & Regulation of cell proliferation & 261 & 578 & $221 \%$ & 521 & $200 \%$ \\
\hline
\end{tabular}

${ }^{\text {a }}$ All means are from 2 animals per group. 
Supplementary Table 1d. Effect of CLA isomers on mouse liver gene expression

\begin{tabular}{|c|c|c|c|c|c|c|c|c|}
\hline \multirow[b]{2}{*}{ Gene name } & \multirow[b]{2}{*}{ probe set (Affimetx) } & \multirow[b]{2}{*}{ Accession \# } & \multirow[b]{2}{*}{ Biological function/Process } & \multirow{2}{*}{$\begin{array}{l}\text { Control } \\
\text { Mean }^{\mathrm{a}}\end{array}$} & \multicolumn{2}{|c|}{$\mathrm{t} 10-, \mathrm{c} 12-\mathrm{CLA}$} & \multicolumn{2}{|c|}{ c9-,t11CLA } \\
\hline & & & & & Mean $^{a}$ & $\%$ Control & Mean $^{a}$ & $\%$ Control \\
\hline A disintegrin and metalloproteinase domain 15 (metargidin) & 1425170_a_at & BC009132 & Proteolysis and peptidolysis & 87.9 & 209 & $237 \%$ & $72 \cdot 8$ & $82 \cdot 8 \%$ \\
\hline RIKEN cDNA 2810433K01 gene & 1425184_at & BG069231 & - & 159 & 57.9 & $36.4 \%$ & 140 & $88.1 \%$ \\
\hline cDNA sequence $\mathrm{BC} 021917$ & 1425300_at & BC021917 & - & 1040 & 2120 & $204 \%$ & 1900 & $183 \%$ \\
\hline zinc finger protein 295 & 1425305_at & BC027135 & Protein binding & 557 & 211 & $37.9 \%$ & 290 & $52 \cdot 1 \%$ \\
\hline RIKEN cDNA 1300007K12 gene & 1425365_a_at & BC018344 & Metabolism & 445 & 212 & $47.6 \%$ & 359 & $80 \cdot 7 \%$ \\
\hline RIKEN cDNA 5730402K07 gene & 1425518_at & AK004874 & Protein amino acid phosphorylation & 988 & 419 & $42.4 \%$ & 580 & $58.7 \%$ \\
\hline RIKEN cDNA $9130022 B 02$ gene & 1425615_a_at & BC010318 & Gluconeogenesis & 276 & 96.7 & $35.0 \%$ & 154 & $55.6 \%$ \\
\hline Cystathionine beta-synthase & 1425623_a_at & BC013480 & Amino acid metabolism & 2170 & 1070 & $49.4 \%$ & 2050 & $94.7 \%$ \\
\hline beta-1,3-glucuronyltransferase 1 & 1425691_at & BM945167 & Glucuronosyltransferase activity & 179 & $67 \cdot 1$ & $37.5 \%$ & 174 & $97.4 \%$ \\
\hline TGF beta 1 induced transcript 4 & 1425742_a_at & AF201285 & Regulation of transcription & 569 & 1380 & $242 \%$ & 1070 & $188 \%$ \\
\hline cDNA sequence BC014805 & 1425751_at & AJ132857 & - & 416 & 83 & $19.9 \%$ & 346 & $83.1 \%$ \\
\hline cDNA sequence BC014805 & 1425752_at & AJ132857 & - & 344 & $70 \cdot 8$ & $20 \cdot 6 \%$ & 219 & $63.8 \%$ \\
\hline Pregnancy-specific glycoprotein 28 & 1425881_at & AF113598 & Pregnancy & 47.4 & 779 & $1640 \%$ & $62 \cdot 4$ & $132 \%$ \\
\hline Sema domain, TM, and cytoplasmic domain $6 \mathrm{~A}$ & 1425903_at & AF288666 & Cell differentiation & 721 & 284 & $39 \cdot 3 \%$ & 466 & $64.6 \%$ \\
\hline RIKEN cDNA 4933433D23 gene & 1425948_a_at & BC022676 & Transport & 225 & 90.5 & $40 \cdot 2 \%$ & 177 & $78 \cdot 7 \%$ \\
\hline Regulator of G-protein signaling 16 & 1426037_a_at & U94828 & Signal transduction & 944 & 371 & $39.3 \%$ & 1420 & $151 \%$ \\
\hline Cullin 4A & 1426060_at & BC007159 & Cell cycle & 52.5 & 250 & $476 \%$ & $63 \cdot 1$ & $120 \%$ \\
\hline Cullin 4A & 1426061_x_at & BC007159 & Cell cycle & 54.8 & 224 & $409 \%$ & $67 \cdot 0$ & $122 \%$ \\
\hline Cytochrome P450, family 3 , subfamily a & 1426064_at & AB039380 & Monooxygenase activity & 1960 & 904 & $46.1 \%$ & 1520 & $77.7 \%$ \\
\hline Ribosome binding protein 1 & 1426123_a_at & AF273691 & Protein transport & 1090 & 508 & $46.8 \%$ & 942 & $86 \cdot 7 \%$ \\
\hline Cryptochrome 2 (photolyase-like) & 1426383_at & BF303057 & Circadian rhythm & 277 & 127 & $45 \cdot 6 \%$ & 215 & $77.4 \%$ \\
\hline Nuclear receptor subfamily 1 , group $D$, member 1 & 1426464_at & W13191 & Regulation of transcription & 373 & 34.7 & $9.31 \%$ & 209 & $55.9 \%$ \\
\hline Signal transducer and activator of transcription 3 & 1426587_a_at & Al325183 & Photoreceptor cell differentiation & 937 & 464 & $49.5 \%$ & 844 & $90.0 \%$ \\
\hline Heterogeneous nuclear ribonucleoprotein M & 1426698_a_at & AK011521 & Nucleic acid binding & 293 & 132 & $44.9 \%$ & 236 & $80 \cdot 6 \%$ \\
\hline Death associated protein kinase 1 & 1426915_at & BC021490 & Protein amino acid phosphorylation & 1060 & 508 & $47 \cdot 8 \%$ & 996 & $93.7 \%$ \\
\hline Cysteine-rich motor neuron 1 & 1426951_at & AK018666 & Regulation of cell growth & 180 & $67 \cdot 7$ & $37.7 \%$ & 130 & $72 \cdot 3 \%$ \\
\hline RIKEN cDNA 4632417N05 gene & 1427082_at & AK014586 & Nucleic acid binding & 925 & 435 & $47.1 \%$ & 866 & $93.7 \%$ \\
\hline RIKEN cDNA 1500031N24 gene & 1427093_at & BC026404 & Regulation of transcription & 305 & 135 & $44.2 \%$ & 258 & $84.6 \%$ \\
\hline FYVE and coiled-coil domain containing 1 & 1427177_at & AJ428065 & - & 220 & 79.7 & $36 \cdot 2 \%$ & 165 & $75.0 \%$ \\
\hline Natriuretic peptide receptor 2 & 1427191_at & AW558468 & cGMP biosynthesis & 558 & 225 & $40 \cdot 3 \%$ & 352 & $63.1 \%$ \\
\hline RIKEN cDNA $2510002 A 14$ gene & 1427199_at & BM118442 & - & 519 & 196 & $37.7 \%$ & 276 & $53 \cdot 1 \%$ \\
\hline Tripartite motif protein 24 & 1427258_at & BB611004 & Regulation of transcription & 430 & 191 & $44.5 \%$ & 402 & $93.6 \%$ \\
\hline Tripartite motif protein 24 & 1427259_at & BB611004 & Regulation of transcription & 309 & 144 & $46.5 \%$ & 278 & $89.8 \%$ \\
\hline
\end{tabular}

${ }^{\text {a }}$ All means are from 2 animals per group. 


\begin{tabular}{|c|c|c|c|c|c|c|c|c|}
\hline \multirow[b]{2}{*}{ Gene name } & \multirow[b]{2}{*}{ probe set (Affimetx) } & \multirow[b]{2}{*}{ Accession \# } & \multirow[b]{2}{*}{ Biological function/Process } & \multirow{2}{*}{$\begin{array}{l}\text { Control } \\
\text { Mean }^{a}\end{array}$} & \multicolumn{2}{|c|}{$\mathrm{t} 10-, \mathrm{c} 12-\mathrm{CLA}$} & \multicolumn{2}{|c|}{ c9-,t11CLA } \\
\hline & & & & & Mean $^{a}$ & $\%$ Control & Mean $^{a}$ & $\%$ Control \\
\hline DNA segment, Chr 11, ERATO Doi 498 & 1427323_s_at & BG068076 & - & 243 & 604 & $249 \%$ & 273 & $113 \%$ \\
\hline CLIP associating protein 2 & 1427328_a_at & BM221361 & Microtubule depolymerization & 73.5 & 196 & $267 \%$ & 142 & $194 \%$ \\
\hline RIKEN cDNA 2810021G02 gene & 1427349_x_at & AK012776 & Regulation of transcription & $93 \cdot 0$ & 202 & $217 \%$ & 79.6 & $86 \%$ \\
\hline Immunoglobulin heavy chain 6 & 1427351_s_at & BB226392 & Activation of MAPK activity & 113 & 233 & $207 \%$ & 160 & $142 \%$ \\
\hline NACHT, leucine rich repeat \& PYD containing 6 & 1427369_at & BB071996 & Nucleic acid binding & 875 & 390 & $44.6 \%$ & 708 & $80.9 \%$ \\
\hline RIKEN cDNA 1300019 J08 gene & 1427370_at & AK005066 & Imidazolonepropionase activity & 1400 & 648 & $46.4 \%$ & 1200 & $85.8 \%$ \\
\hline ATP-binding cassette, sub-family A, member $8 a$ & 1427371_at & BC026496 & Transport & 1300 & 418 & $32 \cdot 2 \%$ & 784 & $60 \cdot 3 \%$ \\
\hline Integrin beta 4 & 1427387_a_at & L04678 & Cell adhesion & 143 & 14.8 & $10 \cdot 3 \%$ & 151 & $105 \%$ \\
\hline Clone:D230030K09 product:unknown EST & 1427410_at & BB812902 & - & 205 & 84.9 & $41.4 \%$ & 107 & $51.9 \%$ \\
\hline RIKEN cDNA 1300018K11 gene & 1427459_at & BC025836 & - & 2000 & 888 & $44.3 \%$ & 1560 & $77.8 \%$ \\
\hline Glutathione S-transferase, mu 3 & 1427473_at & J03953 & Metabolism & 127 & 303 & $238 \%$ & 191 & $150 \%$ \\
\hline Protein tyrosine phosphatase, receptor type, B & 1427486_at & AF157628 & Protein amino acid dephosphorylation & 410 & 204 & $49.6 \%$ & 293 & $71.3 \%$ \\
\hline Zinc finger protein 125 & 1427536_at & Al615965 & Nucleic acid binding & 100 & 240 & $239 \%$ & $93 \cdot 3$ & $93.1 \%$ \\
\hline CD80 antigen & 1427717_at & $\mathrm{X} 60958$ & Defense response & $49 \cdot 1$ & 155 & $315 \%$ & $58 \cdot 4$ & $119 \%$ \\
\hline Splicing factor, arginine/serine-rich 2 (SC-35) & 1427815_at & U14648 & mRNA processing & 146 & 309 & $211 \%$ & 206 & $140 \%$ \\
\hline Tubulin, beta 2 & 1427838_at & M28739 & Microtubule-based process & 131 & 301 & $230 \%$ & 221 & $169 \%$ \\
\hline Acylphosphatase 2, muscle type & 1427943_at & Bl730288 & Acylphosphatase activity & 42.9 & 167 & $390 \%$ & $59 \cdot 8$ & $139 \%$ \\
\hline Clone:9130009H04 product:unknown EST & 1428083_at & AK018202 & - & 1840 & 547 & $29.8 \%$ & 1310 & $71 \cdot 1 \%$ \\
\hline basic transcription element binding protein 1 & 1428289_at & AW488885 & Transcription & 1380 & 473 & $34.3 \%$ & 788 & $57 \cdot 2 \%$ \\
\hline RIKEN cDNA 2610042L04 gene & 1428301_at & BM195235 & - & $32 \cdot 0$ & 161 & $504 \%$ & 28.9 & $90 \cdot 4 \%$ \\
\hline RIKEN cDNA 5830413E08 gene & 1428306_at & AK017926 & - & $67 \cdot 6$ & 220 & $326 \%$ & 156 & $231 \%$ \\
\hline RIKEN cDNA 4121402D02 gene & 1428872_at & AW495537 & - & 441 & 203 & $46.0 \%$ & 300 & $68.0 \%$ \\
\hline RIKEN cDNA 1810013D05 gene & 1429523_a_at & AK008448 & & $25 \cdot 3$ & 184 & $727 \%$ & $60 \cdot 9$ & $241 \%$ \\
\hline Protein geranylgeranyltransferase type I, b subunit & 1429769_at & Bl107300 & & 43.1 & 149 & $345 \%$ & 121 & $280 \%$ \\
\hline Clone:5330406M23 product:unknown EST & 1429900_at & BM241296 & & 499 & 193 & $38.8 \%$ & 571 & $115 \%$ \\
\hline Spermatogenesis associated glutamate-rich prot & 1429993_s_at & AK006975 & & $17 \cdot 8$ & 118 & $663 \%$ & $28 \cdot 3$ & $159 \%$ \\
\hline RIKEN cDNA 4930432J16 gene & 1430076_at & AK015290 & & 223 & 103 & $46.1 \%$ & 208 & $93.0 \%$ \\
\hline RIKEN cDNA 4930539A06 gene & 1430666_at & AK015993 & & 306 & 1090 & $356 \%$ & 235 & $76.9 \%$ \\
\hline kidney-derived aspartic protease-like protein & 1430744_at & AK007861 & & 306 & 81.5 & $26 \cdot 6 \%$ & 187 & $61 \cdot 1 \%$ \\
\hline RIKEN cDNA 1700051112 gene & 1430855_at & AK006759 & & 87.9 & 222 & $253 \%$ & 137 & $156 \%$ \\
\hline RIKEN cDNA 2410030K01 gene & 1431087_at & BF577722 & & 100 & 249 & $250 \%$ & 157 & $157 \%$ \\
\hline Clone:4921537|17 product:unknown EST & 1431259_at & BE635076 & & $59 \cdot 3$ & 225 & $380 \%$ & $62 \cdot 1$ & $105 \%$ \\
\hline
\end{tabular}

${ }^{a}$ All means are from 2 animals per group. 
Supplementary Table 1f. Effect of CLA isomers on mouse liver gene expression

\begin{tabular}{|c|c|c|c|c|c|c|c|c|}
\hline \multirow[b]{2}{*}{ Gene name } & \multirow[b]{2}{*}{ probe set (Affimetx) } & \multirow[b]{2}{*}{ Accession \# } & \multirow[b]{2}{*}{ Biological function/Process } & \multirow{2}{*}{$\begin{array}{l}\text { Control } \\
\text { Mean }^{a}\end{array}$} & \multicolumn{2}{|c|}{ t10-,c12-CLA } & \multicolumn{2}{|c|}{ c9-,t11CLA } \\
\hline & & & & & $\operatorname{Mean}^{\mathrm{a}}$ & $\%$ Control & Mean $^{a}$ & $\%$ Control \\
\hline Clone:9530046B11 product:unknown EST & 1431493_at & AK020596 & & 146 & 361 & $247 \%$ & 120 & $82.3 \%$ \\
\hline RIKEN cDNA 4933404G15 gene & 1431509_at & AV278869 & & 140 & 38.9 & $27 \cdot 8 \%$ & 114 & $80.9 \%$ \\
\hline RIKEN cDNA 2610100K07 gene & 1431571_at & AV283841 & & $61 \cdot 3$ & 204 & $332 \%$ & 63.8 & $104 \%$ \\
\hline Hypothetical protein C330001M22 & 1431698_at & AK020009 & & 103 & 439 & $428 \%$ & 93.0 & $90.5 \%$ \\
\hline Clone:4930422C21 & 1431842_at & AK015175 & & 175 & 71.9 & $41.0 \%$ & 217 & $124 \%$ \\
\hline Clone:2700089124 product:unclassifiable & 1431912_at & AK012591 & & 346 & 113 & $32.6 \%$ & 339 & $97.8 \%$ \\
\hline Acyloxyacyl hydrolase & 1431989_at & AK015300 & & 179 & 370 & $207 \%$ & 213 & $119 \%$ \\
\hline Endothelial cell growth factor 1 (platelet-derived) & 1432181_s_at & AK013765 & Pyrimidine base metabolism & 1990 & 978 & $49.1 \%$ & 2030 & $102 \%$ \\
\hline Clone:2610012C04 product:unclassifiable & 1432606_at & Al120134 & & $55 \cdot 2$ & 172 & $311 \%$ & 107 & $194 \%$ \\
\hline CLONE $=4921527 \mathrm{H} 02$ & 1432694_at & AK014973 & & 11.4 & 203 & $1780 \%$ & $7 \cdot 13$ & $62.4 \%$ \\
\hline gb:AK014604.1 & 1432885_at & AK014604 & & $21 \cdot 7$ & 130 & $598 \%$ & 21.9 & $101 \%$ \\
\hline gb:AK017704.1 & 1433049_at & AK017704 & & $88 \cdot 4$ & 277 & $313 \%$ & $87 \cdot 3$ & $98.8 \%$ \\
\hline Golgi autoantigen, golgin subfamily b, & 1433135_at & AK015226 & & 154 & 49.8 & $32.4 \%$ & 167 & $109 \%$ \\
\hline Cyclin-dependent kinase inhibitor 1A (P21) & 1433359_at & AK006261 & & 378 & 181 & $47.9 \%$ & 266 & $70 \cdot 3 \%$ \\
\hline gb:AK005121.1 & 1433383_at & AK005121 & & 64.7 & 250 & $387 \%$ & 88.0 & $136 \%$ \\
\hline Clone:B930037P14 product: & 1433449_at & BM233059 & & 83.0 & 213 & $256 \%$ & 147 & $178 \%$ \\
\hline RIKEN cDNA 5830434P21 gene & 1433624_at & AV316216 & & 530 & 264 & $49 \cdot 8 \%$ & 405 & $76.4 \%$ \\
\hline RIKEN cDNA E130305N23 gene & 1433632_at & BB183385 & & 303 & 133 & $43.9 \%$ & 264 & $87 \cdot 2 \%$ \\
\hline RIKEN cDNA E130305N23 gene & 1433634_at & BB183385 & & 1190 & 551 & $46.2 \%$ & 1150 & $96.0 \%$ \\
\hline Nischarin & 1433757_a_at & BB025231 & Negative regulation of cell migration & 351 & 147 & $41.9 \%$ & 259 & $73.8 \%$ \\
\hline RIKEN cDNA F830029L24 gene & 1433834_at & BQ176049 & Metal ion binding & 1390 & 682 & $49 \cdot 1 \%$ & 1160 & $83.6 \%$ \\
\hline RIKEN cDNA 8430408 G22 gene & 1433837_at & AV365503 & & 1520 & 431 & $28.3 \%$ & 880 & $57.9 \%$ \\
\hline RIKEN cDNA 4933433D23 gene & 1433898_at & AV000840 & & 586 & 245 & $41.8 \%$ & 537 & $91 \cdot 8 \%$ \\
\hline RIKEN cDNA 5430413K10 (LOC329543) & 1433967_at & Al413838 & & 142 & 30.8 & $21.7 \%$ & 114 & $80.0 \%$ \\
\hline Hypothetical protein C130032F08 & 1434044_at & AV286809 & Inflammatory response & 517 & 204 & $39.5 \%$ & 422 & $81.6 \%$ \\
\hline Solute carrier family 4 , member 4 & 1434096_at & BB283443 & & 720 & 346 & $48.1 \%$ & 624 & $86.7 \%$ \\
\hline Endothelin converting enzyme 1 & 1434177_at & Al551117 & Peptide hormone processing & 1150 & 334 & $29.2 \%$ & 993 & $86.6 \%$ \\
\hline gb:BG076122 & 1434278_at & BG976607 & Phospholipid dephosphorylation & $54 \cdot 8$ & 273 & $498 \%$ & 59.7 & $109 \%$ \\
\hline gb:BG976607 & 1434280_at & BG976607 & - & $25 \cdot 4$ & 242 & $951 \%$ & $17 \cdot 3$ & $68.1 \%$ \\
\hline Transient immune abnormalities & 1434283_at & BB079486 & & 561 & 199 & $35.5 \%$ & 379 & $67.5 \%$ \\
\hline Insulin receptor & 1434446_at & BM206023 & & 679 & 317 & $46.7 \%$ & 524 & $77 \cdot 2 \%$ \\
\hline RIKEN cDNA A130015N09 gene & 1434473_at & Al647939 & & 301 & 130 & $43 \cdot 1 \%$ & 261 & $86.5 \%$ \\
\hline RIKEN cDNA 2610103N14 gene & 1434592_at & BB735478 & & 452 & 212 & $46.9 \%$ & 305 & $67.5 \%$ \\
\hline v-erb-b2 erythroblastic leukemia viral oncogene & 1434606_at & BF140685 & Regulation of cell cycle & 1460 & 532 & $36.5 \%$ & 1040 & $71 \cdot 2 \%$ \\
\hline
\end{tabular}

${ }^{a}$ All means are from 2 animals per group. 
Supplementary Table 1g. Effect of CLA isomers on mouse liver gene expression

\begin{tabular}{|c|c|c|c|c|c|c|c|c|}
\hline \multirow[b]{2}{*}{ Gene name } & \multirow[b]{2}{*}{ probe set (Affimetx) } & \multirow[b]{2}{*}{ Accession \# } & \multirow[b]{2}{*}{ Biological function/Process } & \multirow{2}{*}{$\begin{array}{l}\text { Control } \\
\text { Mean }^{\mathrm{a}}\end{array}$} & \multicolumn{2}{|c|}{$\mathrm{t} 10-, \mathrm{c} 12-\mathrm{CLA}$} & \multicolumn{2}{|c|}{ c9-,t11CLA } \\
\hline & & & & & Mean $^{a}$ & $\%$ Control & Mean $^{\mathrm{a}}$ & $\%$ Control \\
\hline Similar to Cdc42-binding protein kinase beta & 1434652_at & Bl154551 & & 259 & 122 & $47 \cdot 2 \%$ & 270 & $104 \%$ \\
\hline Forkhead box $\mathrm{O} 3$ & 1434831_a_at & BB364488 & Regulation of transcription & 263 & 128 & $48.5 \%$ & 198 & $75.4 \%$ \\
\hline Carnitine palmitoyltransferase $1 \mathrm{a}$, liver & 1434866_x_at & BB021753 & Lipid metabolism & 1070 & 435 & $40.7 \%$ & 827 & $77.4 \%$ \\
\hline Two pore channel 1 & 1434930_at & Bl904914 & - & 480 & 222 & $46.3 \%$ & 426 & $88.6 \%$ \\
\hline DNA segment, Chr 4, Wayne State University 53 & 1435357_at & BE652553 & - & 334 & 167 & $49.8 \%$ & 273 & $81.6 \%$ \\
\hline Expressed sequence Al464131 & 1435417_at & BG063189 & - & 257 & 128 & $49 \cdot 8 \%$ & 239 & $92.9 \%$ \\
\hline Mus musculus transcribed sequences & 1435436_at & Bl647951 & & 1600 & 618 & $38.6 \%$ & 1590 & $99.2 \%$ \\
\hline Flavin containing monooxygenase 2 & 1435459_at & BM936480 & & 290 & 58.7 & $20.3 \%$ & 225 & $77.7 \%$ \\
\hline Clone:C030039M13 product:RAN binding protein 16 , & 1435814_at & BB198104 & & $15 \cdot 2$ & 126 & $831 \%$ & $10 \cdot 7$ & $70 \cdot 1 \%$ \\
\hline RIKEN cDNA 1810063 B05 gene & 1435864_a_at & BG975168 & - & 371 & 820 & $221 \%$ & 409 & $110 \%$ \\
\hline Contrapsin-like protease inhibitor-related protein & 1435887_at & BB806208 & & 1270 & 607 & $47.9 \%$ & 941 & $74.2 \%$ \\
\hline RIKEN cDNA 5430400N05 gene & 1435954_at & BG069330 & & 444 & 922 & $208 \%$ & 456 & $103 \%$ \\
\hline Clone:6430557009 & 1435961_at & BB702376 & & $1 \cdot 28$ & 109 & $8480 \%$ & 0.480 & $37.5 \%$ \\
\hline Similarity to protein ref:NP_057365.1 & 1435964_a_at & BB194075 & - & 718 & 228 & $31.8 \%$ & 449 & $62.6 \%$ \\
\hline Clone:4930512101 & 1436054_at & BM220028 & & 422 & 146 & $34.5 \%$ & 284 & $67.3 \%$ \\
\hline Mus musculus transcribed sequences & 1436093_at & BE981269 & & 655 & 277 & $42 \cdot 3 \%$ & 457 & $69 \cdot 8 \%$ \\
\hline DNA Segment, Mouse Genome Informatics 8 & 1436128_at & Al324154 & & 89.4 & 200 & $223 \%$ & 98.7 & $110 \%$ \\
\hline LISCH7-like & 1436221_at & BG067625 & & 208 & 93.2 & $44.8 \%$ & 159 & $76 \cdot 3 \%$ \\
\hline Clone:B230214O09 product:unknown EST & 1436240_at & BM211445 & & 212 & $99 \cdot 1$ & $46.7 \%$ & 111 & $52 \cdot 3 \%$ \\
\hline LISCH7-like & 1436293_x_at & Al852300 & & 444 & 196 & $44.1 \%$ & 296 & $66.8 \%$ \\
\hline Clone:B930092N05 product:unknown EST, & 1436317_at & BM115569 & & 186 & 83.8 & $45.1 \%$ & 89.7 & $48.3 \%$ \\
\hline Nuclear factor $\mathrm{I} / \mathrm{X}$ & 1436363_a_at & AW049660 & DNA replication & 1040 & 346 & $33.1 \%$ & 647 & $62.0 \%$ \\
\hline Nuclear factor $\mathrm{I} / \mathrm{X}$ & 1436364_x_at & AW049660 & DNA replication & 1000 & 333 & $33.2 \%$ & 642 & $64.1 \%$ \\
\hline RIKEN cDNA B830010L13 gene & 1436731_at & BB333374 & & 230 & 74.2 & $32.3 \%$ & 118 & $51.5 \%$ \\
\hline Angiotensin receptor 1 & 1436739_at & Al551199 & & 1070 & 527 & $49.4 \%$ & 1090 & $102 \%$ \\
\hline aarF domain containing kinase 5 & 1436753_at & BB317588 & & 275 & 135 & $49.1 \%$ & 220 & $80.2 \%$ \\
\hline Basic transcription element binding protein 1 & 1436763_a_at & Al267126 & Transcription & 282 & 122 & $43.1 \%$ & 166 & $58.8 \%$ \\
\hline Partitioning defective 3 homolog (C. elegans) & 1436764_at & BE199556 & & 329 & 144 & $43.9 \%$ & 247 & $75.2 \%$ \\
\hline RIKEN cDNA 4933433D23 gene & 1437073_x_at & BB115446 & & 911 & 409 & $44.9 \%$ & 800 & $87.9 \%$ \\
\hline Proviral integration site 3 & $1437100 \_$x_at & BB206220 & Protein amino acid phosphorylation & 397 & 196 & $49.4 \%$ & 438 & $110 \%$ \\
\hline Fibronectin 1 & 1437218_at & BM234360 & Acute-phase response & 406 & 163 & $40 \cdot 1 \%$ & 359 & $88.4 \%$ \\
\hline Scavenger receptor class B, member 1 & 1437378_x_at & BB224405 & Cell adhesion & 927 & 327 & $35.3 \%$ & 557 & $60.1 \%$ \\
\hline Expressed sequence Al987712 & 1437397_at & AW554594 & & 1010 & 359 & $35.4 \%$ & 606 & $59.7 \%$ \\
\hline Clone:C130020M04:transcription factor & 1437645 at & BE225843 & Transcription & 295 & 134 & $45.3 \%$ & 176 & $59.8 \%$ \\
\hline
\end{tabular}

${ }^{a}$ All means are from 2 animals per group. 
Supplementary Table 1h. Effect of CLA isomers on mouse liver gene expression

\begin{tabular}{|c|c|c|c|c|c|c|c|c|}
\hline \multirow[b]{2}{*}{ Gene name } & \multirow[b]{2}{*}{ probe set (Affimetx) } & \multirow[b]{2}{*}{ Accession \# } & \multirow[b]{2}{*}{ Biological function/Process } & \multirow{2}{*}{$\begin{array}{l}\text { Control } \\
\text { Meann }^{a}\end{array}$} & \multicolumn{2}{|c|}{$\mathrm{t} 10-, \mathrm{c} 12-\mathrm{CLA}$} & \multicolumn{2}{|c|}{ c9-,t11CLA } \\
\hline & & & & & Mean $^{a}$ & $\%$ Control & Mean $^{\mathrm{a}}$ & $\%$ Control \\
\hline Annexin A2 & 1437692_x_at & AW240637 & Angiogenesis & 187 & 492 & $263 \%$ & 229 & $122 \%$ \\
\hline Sal-like 1 (Drosophila) & 1437983_at & BB739342 & & 406 & 188 & $46 \cdot 2 \%$ & 301 & $74.1 \%$ \\
\hline Spinocerebellar ataxia 2 homolog (human) & 1438143_s_at & BB705334 & - & 686 & 299 & $43.7 \%$ & 609 & $88.8 \%$ \\
\hline Carnitine palmitoyltransferase $1 \mathrm{a}$, liver & 1438156_x_at & BB119196 & Lipid metabolism & 970 & 379 & $39.1 \%$ & 733 & $75.6 \%$ \\
\hline Solute carrier family 1 , member 2 & 1438194_at & AW488243 & & 542 & 247 & $45 \cdot 6 \%$ & 360 & $66.4 \%$ \\
\hline Mus musculus transcribed sequences & 1438245_at & Bl664122 & - & 476 & 203 & $42.7 \%$ & 252 & $52.9 \%$ \\
\hline Cysteine conjugate-beta lyase & 1438348_x_at & BB039821 & & 330 & 160 & $48.3 \%$ & 245 & $74.0 \%$ \\
\hline Zinc finger protein 288 & 1438443_at & BB751546 & DNA binding & 625 & 298 & $47.7 \%$ & 428 & $68.5 \%$ \\
\hline Similar to PRAMEI4 (LOC384075), mRNA & 1438468_at & BG070047 & - & 348 & 155 & $44.5 \%$ & 338 & $97.1 \%$ \\
\hline Hypothetical protein E130112L23 & 1438485_at & BB770854 & - & 203 & 84.5 & $41.7 \%$ & 175 & $86.5 \%$ \\
\hline RIKEN cDNA A630025009 gene & 1438596_at & AW114007 & & 479 & 202 & $42 \cdot 1 \%$ & 329 & $68.6 \%$ \\
\hline Mus musculus transcribed sequences & 1438643_at & BB230839 & & 424 & 158 & $37.3 \%$ & 274 & $64.6 \%$ \\
\hline Calmin & 1439117_at & AU067755 & & 409 & 184 & $44.9 \%$ & 241 & $58.9 \%$ \\
\hline Clone:B230308F23 product:unknown EST, & 1439128_at & Al595815 & & 561 & 270 & $48.0 \%$ & 346 & $61 \cdot 6 \%$ \\
\hline Deltex 2 homolog (Drosophila) & 1439429_x_at & BB518874 & Notch signaling pathway & 147 & $45 \cdot 4$ & $30.9 \%$ & 100 & $68.4 \%$ \\
\hline Phosphoenolpyruvate carboxykinase 1 , cytosolic & 1439617_s_at & Al265463 & & 1260 & 305 & $24.1 \%$ & 772 & $61 \cdot 1 \%$ \\
\hline CLONE = 9330161F22 /UG_TITLE = ESTs, & 1439920_at & BB080140 & & 38.7 & 387 & $999 \%$ & 38.7 & $100 \%$ \\
\hline Clone:C130042N08/ KIAA1276 protein & 1440200_at & BB128528 & & 202 & 37.3 & $18.5 \%$ & 105 & $52.1 \%$ \\
\hline CLONE $=$ C630033O16 $/ \mathrm{FEA}=\mathrm{EST}$ & 1440508_at & BB430574 & & $52 \cdot 1$ & 178 & $342 \%$ & $56 \cdot 9$ & $109 \%$ \\
\hline Mus musculus transcribed sequences & 1440730_at & BB284266 & & 40 & 155 & $386 \%$ & 99.8 & $249 \%$ \\
\hline Mus musculus transcribed sequences & 1440790_x_at & BB394466 & & 256 & 103 & $40 \cdot 3 \%$ & 159 & $62.0 \%$ \\
\hline CLONE $=9430066017 /$ UG_TITLE $=$ ESTs & 1440815_x_at & BB099075 & & $26 \cdot 3$ & 137 & $520 \%$ & $24 \cdot 6$ & $93.3 \%$ \\
\hline cDNA sequence BC035291 & 1440836_at & BB090304 & & 324 & 155 & $47.7 \%$ & 293 & $90.4 \%$ \\
\hline METASTASIS SUPPRESSOR PROTEIN homolog & 1440847_at & BB326749 & & 302 & 101 & $33.5 \%$ & 177 & $58.4 \%$ \\
\hline RIKEN cDNA $2510049 J 12$ gene & 1440916_at & BE200006 & & 136 & 408 & $301 \%$ & 193 & $142 \%$ \\
\hline Leucine-rich-repeat protein & 1440921_at & Al527293 & & 359 & 69.7 & $19.4 \%$ & 204 & $56 \cdot 8 \%$ \\
\hline RAR-related orphan receptor alpha & 1441085_at & AW494655 & & 56.4 & 223 & $396 \%$ & $60 \cdot 5$ & $107 \%$ \\
\hline Expressed sequence Al987712 & 1441102_at & BB429201 & & 199 & $86 \cdot 1$ & $43.2 \%$ & 148 & $74.0 \%$ \\
\hline Clone:5430414B12 product:unknown EST & 1441109_at & BG070250 & & 117 & 266 & $227 \%$ & 231 & $197 \%$ \\
\hline Mbt domain containing 1 & 1441287_at & BB369299 & & 231 & 113 & $49.1 \%$ & 243 & $105 \%$ \\
\hline Mus musculus transcribed sequences & 1441343_at & BG070780 & & 251 & 101 & $40 \cdot 2 \%$ & 237 & $94.5 \%$ \\
\hline Mus musculus transcribed sequences & 1441392_at & BB307362 & & 150 & 47.5 & $31.7 \%$ & 112 & $74.7 \%$ \\
\hline RIKEN cDNA 1110056A04 gene & 1441551_at & BB196537 & & 229 & 111 & $48.5 \%$ & 198 & $86.6 \%$ \\
\hline
\end{tabular}

${ }^{\text {a } A l l ~ m e a n s ~ a r e ~ f r o m ~} 2$ animals per group. 
Supplementary Table 1i. Effect of CLA isomers on mouse liver gene expression

\begin{tabular}{|c|c|c|c|c|c|c|c|c|}
\hline \multirow[b]{2}{*}{ Gene name } & \multirow[b]{2}{*}{ probe set (Affimetx) } & \multirow[b]{2}{*}{ Accession \# } & \multirow[b]{2}{*}{ Biological function/Process } & \multirow{2}{*}{$\begin{array}{l}\text { Control } \\
\text { Mean }^{a}\end{array}$} & \multicolumn{2}{|c|}{$\mathrm{t} 10-, \mathrm{c} 12-\mathrm{CLA}$} & \multicolumn{2}{|c|}{ c9-,t11CLA } \\
\hline & & & & & Mean $^{\mathrm{a}}$ & $\%$ Control & Mean $^{a}$ & $\%$ Control \\
\hline Mus musculus transcribed sequences & 1441580_at & AW551517 & & 113 & 230 & $203 \%$ & 176 & $155 \%$ \\
\hline Clone:9530006C21 product:unknown EST & 1441779_at & BB750043 & & 270 & 130 & $48.1 \%$ & 161 & $59.6 \%$ \\
\hline RIKEN cDNA 4930471K13 gene & 1441790_at & AW489900 & & 111 & 253 & $228 \%$ & 130 & $117 \%$ \\
\hline RIKEN cDNA 1500031N24 gene & 1441842_s_at & AV031885 & & 273 & 92.8 & $34.0 \%$ & 175 & $63.9 \%$ \\
\hline Clone:B230330B21 product:unknown EST & 1442416_at & BB311940 & & 92.5 & 207 & $223 \%$ & 89.7 & $96.9 \%$ \\
\hline Mus musculus transcribed sequences & 1442593_at & AW553880 & & 460 & 190 & $41.2 \%$ & 291 & $63.3 \%$ \\
\hline Mus musculus transcribed sequences & 1442688_at & BG084733 & & 14.6 & 144 & $993 \%$ & - & - \\
\hline Mus musculus transcribed sequences & 1442694_at & BG066676 & - & 157 & $50 \cdot 4$ & $32.1 \%$ & 105 & $66.6 \%$ \\
\hline Phosphodiesterase 4B, cAMP specific & 1442700_at & BG793493 & & 256 & 126 & $49.4 \%$ & 231 & $90.3 \%$ \\
\hline Clone:A130024J23 product:unknown EST, & 1442812_at & BB155332 & & 19.9 & 130 & $653 \%$ & 14.9 & $74.9 \%$ \\
\hline Mus musculus transcribed sequences & 1443147_at & BB505010 & & 830 & 207 & $24.9 \%$ & 914 & $110 \%$ \\
\hline Mus musculus transcribed sequences & 1443516_at & BE953583 & & 189 & 83.6 & $44.2 \%$ & 127 & $67.4 \%$ \\
\hline Sorbin and SH3 domain containing 1 & 1443983_at & BB218653 & & 180 & 68.7 & $38.1 \%$ & 120 & $66.6 \%$ \\
\hline RIKEN cDNA A130090K04 gene & 1444298_at & BB703415 & & 119 & 247 & $207 \%$ & 203 & $170 \%$ \\
\hline RIKEN cDNA A130039l20 gene & 1444311_at & BB138395 & & 151 & 46.6 & $30.9 \%$ & 175 & $116 \%$ \\
\hline APLT class I, type 8A, member 1 & 1444355_at & AW125445 & & 33.5 & 135 & $401 \%$ & 112 & $334 \%$ \\
\hline Clone:D630017L16 product:EST & 1444425_at & BE994902 & & 0.160 & 134 & $83500 \%$ & 60.6 & $37900 \%$ \\
\hline M.musculus S12207 hypothetical protein & 1444458_at & Al593288 & & 228 & 103 & $45.2 \%$ & 147 & $64.3 \%$ \\
\hline Mus musculus transcribed sequences & 1444518_at & BM240237 & & 374 & 175 & $46.7 \%$ & 401 & $107 \%$ \\
\hline Clone:A830083P21 product:unknown EST & 1444627_at & BB273517 & & 119 & 292 & $245.0 \%$ & 158 & $133 \%$ \\
\hline Mus musculus transcribed sequences & 1444700_at & BE985761 & & $70 \cdot 7$ & 176 & $248.0 \%$ & 137 & $194 \%$ \\
\hline gb:BG069414 & 1444927_at & BG069414 & & 30.0 & 177 & $591 \%$ & $22 \cdot 7$ & $75.7 \%$ \\
\hline gb:BG066639 & 1445196_at & BG066639 & & 257 & 122 & $47.5 \%$ & 267 & $104 \%$ \\
\hline Killer cell lectin-like receptor subfamily B & 1445399_at & AV294178 & & 677 & 231 & $34.1 \%$ & 505 & $74.6 \%$ \\
\hline Clone:6430400O22 product:unknown EST & 1445402_at & AV337434 & & 268 & 112 & $41.7 \%$ & 175 & $65.5 \%$ \\
\hline cDNA sequence $\mathrm{BC} 031575$ & 1445862_at & BB123487 & & 307 & 142 & $46 \cdot 2 \%$ & 169 & $55.1 \%$ \\
\hline RIKEN cDNA C730034F03 gene & 1446063_at & BB667700 & & 188 & $67 \cdot 1$ & $35.6 \%$ & 124 & $65.6 \%$ \\
\hline Clone:7030419G12 product:unknown EST & 1446270_at & BB535337 & & $32 \cdot 3$ & 144 & $446 \%$ & 121 & $375 \%$ \\
\hline gb:BG068594 /UG_TITLE = ESTs & 1446602_at & BG068594 & & 96.6 & 205 & $212 \%$ & 108 & $111 \%$ \\
\hline Mus musculus transcribed sequences & 1446848_at & C77955 & & 196 & 83.7 & $42.8 \%$ & 130 & $66.2 \%$ \\
\hline M.musculus S12207 hypothetical protein & 1446850_at & BM234464 & & 225 & 83.4 & $37 \cdot 1 \%$ & 175 & $77.9 \%$ \\
\hline Mus musculus transcribed sequences & 1447121_at & BM224713 & & 264 & 102 & $38.5 \%$ & 142 & $53.9 \%$ \\
\hline
\end{tabular}

${ }^{a}$ All means are from 2 animals per group. 
Supplementary Table 1j. Effect of CLA isomers on mouse liver gene expression

\begin{tabular}{|c|c|c|c|c|c|c|c|c|}
\hline \multirow[b]{2}{*}{ Gene name } & \multirow[b]{2}{*}{ probe set (Affimetx) } & \multirow[b]{2}{*}{ Accession \# } & \multirow[b]{2}{*}{ Biological function/Process } & \multirow{2}{*}{$\begin{array}{l}\text { Control } \\
\text { Mean }^{a}\end{array}$} & \multicolumn{2}{|c|}{$\mathrm{t} 10-, \mathrm{c} 12-\mathrm{CLA}$} & \multicolumn{2}{|c|}{ c9-,t11CLA } \\
\hline & & & & & Mean $^{a}$ & $\%$ Control & Mean $^{a}$ & $\%$ Control \\
\hline gb:AI647619/UG_TITLE = ESTs & 1447172_at & Al647619 & & 275 & 137 & $49.9 \%$ & 207 & $75 \cdot 3 \%$ \\
\hline gb:Al506532 / /UG__TITLE = ESTs, & 1447329_at & Al506532 & & 11.1 & 140 & $1260 \%$ & 9.47 & $85.7 \%$ \\
\hline gb:BE954474/UG_TITLE = ESTs & 1447458_at & BE954474 & & 1080 & 334 & $31.1 \%$ & 676 & $62.8 \%$ \\
\hline Clone:2900006A08 product:unknown EST & 1448019_at & BE849316 & - & 322 & 152 & $47.4 \%$ & 266 & $82.7 \%$ \\
\hline Mus musculus transcribed sequences & 1448080_at & Al256288 & & 695 & 236 & $34.0 \%$ & 478 & $68.8 \%$ \\
\hline Kruppel-like factor 15 & 1448181_at & BC013486 & Transcription & 822 & 390 & $47.5 \%$ & 640 & $77.9 \%$ \\
\hline Histone $\mathrm{H} 1$-like protein in spermatids 1 & 1448512_at & NM_018792 & Transcription & $92 \cdot 0$ & 215 & $234 \%$ & 145 & $157 \%$ \\
\hline Lipopolysaccharide binding protein & 1448550_at & NM_008489 & Lipid transport & 1640 & 764 & $46.6 \%$ & 1160 & $70.5 \%$ \\
\hline Prolactin receptor & 1448556_at & BC005555 & Regulation of cell adhesion & 774 & 213 & $27 \cdot 6 \%$ & 436 & $56.4 \%$ \\
\hline RIKEN cDNA 2310066P17 gene & 1448626_at & NM_025876 & Metal ion binding & 258 & 105 & $40.7 \%$ & 309 & $120 \%$ \\
\hline Low density lipoprotein receptor-related protein 1 & 1448655_at & NM_008512 & Lipid metabolism & 1560 & 760 & $48.9 \%$ & 1400 & $89.7 \%$ \\
\hline Occludin & 1448873_at & NM_008756 & Protein binding & 243 & $83 \cdot 3$ & $34.3 \%$ & 143 & $58.9 \%$ \\
\hline Lactoperoxidase & 1448998_at & NM_080420 & Peroxidase activity & 1150 & 510 & $44.4 \%$ & 820 & $71.3 \%$ \\
\hline Kallikrein B, plasma 1 & 1449034_at & BC026555 & Inflammatory response & 2910 & 1380 & $47.5 \%$ & 2110 & $72.5 \%$ \\
\hline Peroxisome proliferator activated receptor alpha & 1449051_at & BC016892 & Glucose / lipid metabolism & 1700 & 795 & $46.8 \%$ & 1390 & $81.8 \%$ \\
\hline Dihydrolipoamide branched chain transacylase E2 & 1449118_at & NM_010022 & Metabolism & 577 & 288 & $49.9 \%$ & 396 & $68.6 \%$ \\
\hline Midnolin & 1449188_at & NM_021565 & - & 346 & 173 & $49.8 \%$ & 320 & $92.3 \%$ \\
\hline Ribosome binding protein 1 & 1449221_a_at & NM_133626 & Protein targeting & 1150 & 542 & $46.9 \%$ & 981 & $84.9 \%$ \\
\hline Kelch-like 1 (Drosophila) & 1449241_at & NM_053105 & Actin binding & 19.4 & 138 & $710 \%$ & $15 \cdot 7$ & $80.9 \%$ \\
\hline Cytochrome P450, family 4, subfamily $f$ & 1449316_at & NM_134127 & Electron transport & 1690 & 641 & $37.8 \%$ & 1200 & $71.1 \%$ \\
\hline RIKEN cDNA $9130231 \mathrm{C} 15$ gene & 1449375_at & NM_133960 & Carboxylesterase activity & 1220 & 557 & $45.5 \%$ & 997 & $81.5 \%$ \\
\hline Hydroxysteroid (17-beta) dehydrogenase 9 & 1449385_at & NM_013786 & Metabolism & 2280 & 793 & $34.8 \%$ & 1260 & $55.4 \%$ \\
\hline Flavin containing monooxygenase 3 & 1449525_at & NM_008030 & Electron transport & 1820 & 30 & $1.65 \%$ & 1010 & $55.6 \%$ \\
\hline Fetuin beta & 1449555_a_at & NM_021564 & Cysteine protease inhibitor activity & 3680 & 1510 & $41.0 \%$ & 3030 & $82.1 \%$ \\
\hline Nuclear receptor subfamily 0 , group B, member 2 & 1449854_at & BC019540 & Transcription & 509 & 188 & $36.9 \%$ & 566 & $111 \%$ \\
\hline Hyaluronidase 1 & 1449954_at & NM_008317 & Cell cycle & 238 & 112 & $46.9 \%$ & 186 & $78.1 \%$ \\
\hline Polymeric immunoglobulin receptor & 1450060_at & NM_011082 & Receptor activity & 3390 & 1340 & $39.5 \%$ & 2850 & $84.2 \%$ \\
\hline Growth arrest specific 2 & 1450112_a_at & NM_008087 & Apoptosis & 280 & 582 & $208 \%$ & 314 & $112 \%$ \\
\hline Clone:E330039102 product:weakly similar FRAGMENT & 1450192_at & NM_013582 & Signal transduction & $47 \cdot 2$ & 151 & $320 \%$ & 53.1 & $113 \%$ \\
\hline RIKEN cDNA C730049F20 gene & 1450717_at & NM_007447 & Cell differentiation & 3070 & 1160 & $37.9 \%$ & 1890 & $61.7 \%$ \\
\hline CD36 antigen & 1450883_a_at & BB534670 & Transport / cell adhesion & 570 & 1480 & $259 \%$ & 848 & $149 \%$ \\
\hline CD36 antigen & 1450884_at & BB534670 & Transport / cell adhesion & $92 \cdot 0$ & 212 & $231 \%$ & $97 \cdot 9$ & $106 \%$ \\
\hline
\end{tabular}

${ }^{a}$ All means are from 2 animals per group. 
Supplementary Table 1k. Effect of CLA isomers on mouse liver gene expression

\begin{tabular}{|c|c|c|c|c|c|c|c|c|}
\hline \multirow[b]{2}{*}{ Gene name } & \multirow[b]{2}{*}{ probe set (Affimetx) } & \multirow[b]{2}{*}{ Accession \# } & \multirow[b]{2}{*}{ Biological function/Process } & \multirow{2}{*}{$\begin{array}{l}\text { Control } \\
\text { Mean }^{\mathrm{a}}\end{array}$} & \multicolumn{2}{|c|}{ t10-,c12-CLA } & \multicolumn{2}{|c|}{ c9-,t11CLA } \\
\hline & & & & & Mean $^{a}$ & $\%$ Control & Mean $^{a}$ & $\%$ Control \\
\hline Fusion, derived from $\mathrm{t}(12 ; 16)$ malignant liposarcoma & 1451285_at & AF224264 & Regulation of transcription & 564 & 233 & $41.4 \%$ & 699 & $124 \%$ \\
\hline Expressed sequence R75183 & 1451348_at & BC004774 & Rntracellular signaling cascade & 1350 & 597 & $44.2 \%$ & 882 & $65.4 \%$ \\
\hline Regulator of G-protein signaling 16 & 1451452_a_at & U72881 & Regulation of signal transduction & 218 & 107 & $49.2 \%$ & 402 & $184 \%$ \\
\hline Solute carrier family 22, member 7 & 1451460_a_at & BC026598 & Ion transport / & 430 & 176 & $41.0 \%$ & 281 & $65.3 \%$ \\
\hline RIKEN cDNA 1110028A07 gene & 1451488_at & AB054000 & - & 112 & 396 & $353 \%$ & 199 & $177 \%$ \\
\hline RIKEN cDNA 4930438M06 gene & 1451543_at & BC021871 & Ubiquitin cycle & 337 & 161 & $47 \cdot 8 \%$ & 231 & $68.7 \%$ \\
\hline Solute carrier family 1 , member 2 & 1451627_a_at & U75372 & Dicarboxylic acid transport & 504 & 231 & $45.8 \%$ & 399 & $79.1 \%$ \\
\hline Hypothetical protein D630002G06 & 1451635_at & AB056443 & Protein targeting & 98 & 246 & $251 \%$ & 126 & $128 \%$ \\
\hline C/EBP, gamma & 1451639_at & AB012273 & Regulation of transcription & 143 & 299 & $208 \%$ & 230 & $160 \%$ \\
\hline cis-retinol/3alpha hydroxysterol short-chain dehydrogenase-like & 1451681_at & BC018263 & - & 2840 & 1370 & $48.1 \%$ & 2540 & $89.4 \%$ \\
\hline v-maf musculoaponeurotic fibrosarcoma oncogene & 1451716_at & AW412521 & Transcription & 213 & $50 \cdot 7$ & $23.8 \%$ & 261 & $123 \%$ \\
\hline Two pore channel 1 & 1451772_at & AF217002 & - & 304 & 144 & $47 \cdot 2 \%$ & 228 & $75.0 \%$ \\
\hline Coagulation factor XI & 1451788_at & AF356627 & Proteolysis and peptidolysis & 465 & 226 & $48.6 \%$ & 355 & $76.4 \%$ \\
\hline RIKEN cDNA $9130422 \mathrm{G} 05$ gene & 1452008_at & AK018685 & - & 208 & $90 \cdot 8$ & $43.7 \%$ & 126 & $60 \cdot 8 \%$ \\
\hline RIKEN cDNA 2010005A06 gene & 1452294_at & AK008111 & Homophilic cell adhesion & 554 & 220 & $39.7 \%$ & 500 & $90.4 \%$ \\
\hline DNA segment, Chr 14, & 1452406_x_at & AJ007909 & - & 230 & 114 & $49.5 \%$ & 289 & $126 \%$ \\
\hline gb:BB662083 & 1452433_at & BB662083 & - & 120 & 425 & $355 \%$ & 119 & $99.6 \%$ \\
\hline gb:X14678.1 /UG_TITLE = zinc finger protein 36 & 1452519_a_at & X14678 & mRNA catabolism & 1190 & 484 & $40 \cdot 7 \%$ & 1350 & $114 \%$ \\
\hline Cysteine conjugate-beta lyase & 1452678_a_at & AK008165 & & 420 & 183 & $43.5 \%$ & 297 & $70 \cdot 8 \%$ \\
\hline Cullin 5 & 1452722_a_at & BB702110 & & $25 \cdot 9$ & 153 & $589 \%$ & 126 & $485 \%$ \\
\hline RIKEN cDNA 4930438D12 gene & 1452943_at & BF383782 & & $40 \cdot 3$ & 264 & $654 \%$ & $76 \cdot 7$ & $190 \%$ \\
\hline Sestrin 3 & 1453313_at & AK017464 & & 381 & 189 & $49.5 \%$ & 271 & $71.1 \%$ \\
\hline RIKEN cDNA 3830408 G10 gene & 1453345_at & AK014427 & & 425 & 188 & $44.3 \%$ & 274 & $64.6 \%$ \\
\hline RIKEN cDNA 1500005J14 gene & 1453369_a_at & AK007686 & - & 167 & 336 & $201 \%$ & 215 & $128 \%$ \\
\hline Flavin containing monooxygenase 2 & 1453435_a_at & AK009753 & & 249 & $73 \cdot 3$ & $29.4 \%$ & 203 & $81.6 \%$ \\
\hline Insulin-like growth factor binding protein 2 & 1454159_a_at & AK011784 & Regulation of cell growth & 3820 & 1070 & $28 \cdot 1 \%$ & 2660 & $69.7 \%$ \\
\hline Expressed sequence Al450344 & 1454617_at & BG072824 & & 1830 & 792 & $43.2 \%$ & 1260 & $68.9 \%$ \\
\hline RIKEN cDNA E430026E19 gene & 1454646_at & BM245221 & & 276 & 134 & $48.6 \%$ & 161 & $58.4 \%$ \\
\hline Spermatogenesis associated 13 & 1454656_at & AV271736 & - & 311 & 147 & $47.4 \%$ & 201 & $64.9 \%$ \\
\hline TGF beta 1 induced transcript 4 & 1454758_a_at & AU016382 & Regulation of transcription, & 388 & 852 & $220 \%$ & 691 & $178 \%$ \\
\hline Retinoid $\mathrm{X}$ receptor alpha & 1454773_at & BQ175050 & - & 1270 & 619 & $48.9 \%$ & 1070 & $84.7 \%$ \\
\hline Fibrillin 2 & 1454830_at & AV010392 & & 209 & 61.9 & $29.6 \%$ & 127 & $60.9 \%$ \\
\hline gb:BG066923 / = ectodermal-neural cortex 1 & 1454904_at & BG976607 & Phospholipid dephosphorylation & $50 \cdot 6$ & 200 & $394 \%$ & $56 \cdot 4$ & $111 \%$ \\
\hline
\end{tabular}

${ }^{\text {a } A l l ~ m e a n s ~ a r e ~ f r o m ~} 2$ animals per group. 
Supplementary Table 1I. Effect of CLA isomers on mouse liver gene expression

\begin{tabular}{|c|c|c|c|c|c|c|c|c|}
\hline \multirow[b]{2}{*}{ Gene name } & \multirow[b]{2}{*}{ probe set (Affimetx) } & \multirow[b]{2}{*}{ Accession \# } & \multirow[b]{2}{*}{ Biological function/Process } & \multirow{2}{*}{$\begin{array}{l}\text { Control } \\
\text { Mean }^{a}\end{array}$} & \multicolumn{2}{|c|}{$\mathrm{t} 10-, \mathrm{c} 12-\mathrm{CLA}$} & \multicolumn{2}{|c|}{ c9-,t11CLA } \\
\hline & & & & & Mean $^{a}$ & $\%$ Control & Mean $^{a}$ & $\%$ Control \\
\hline Mus musculus transcribed sequences & 1454971_x_at & BB357514 & Regulation of transcription & 680 & 1610 & $237 \%$ & 1160 & $171 \%$ \\
\hline Clone:D330042l16 product:unknown EST & 1454984_at & AV246615 & - & 1720 & 548 & $31.8 \%$ & 1290 & $75.2 \%$ \\
\hline Regulator of G-protein signaling 16 & 1455265_a_at & BB100249 & Regulation of signal transduction & 691 & 306 & $44 \cdot 2 \%$ & 926 & $134 \%$ \\
\hline Preferred translocation partner in lipoma & 1455314_at & BM236111 & & 805 & 379 & $47.1 \%$ & 612 & $76 \cdot 1 \%$ \\
\hline Clone:D930035P11 product:unknown EST & 1455324_at & BQ176176 & & 803 & 345 & $43.0 \%$ & 538 & $67.0 \%$ \\
\hline Angiopoietin 4 & 1455427_at & AV269710 & & 98.8 & 250 & $253 \%$ & 21.6 & $21.9 \%$ \\
\hline Lectin, galactose binding, soluble 1 & 1455439_a_at & Al642438 & Myoblast differentiation & 324 & 1510 & $465 \%$ & 507 & $157 \%$ \\
\hline Polymeric immunoglobulin receptor & 1455490_at & AV027632 & Regulation of transcription & 5020 & 2280 & $45.4 \%$ & 4370 & $87.0 \%$ \\
\hline H.sapiens STE20-like kinase & 1455733_at & AW208927 & Threonine kinase activity & 541 & 183 & $33.8 \%$ & 395 & $73.0 \%$ \\
\hline Endothelin converting enzyme 1 & 1455741_a_at & AW553715 & Peptide hormone processing & 895 & 396 & $44.2 \%$ & 865 & $96.5 \%$ \\
\hline Scavenger receptor class $\mathrm{B}$, member 1 & 1455820 x_at & BB138434 & Cell adhesion & 555 & 167 & $30.1 \%$ & 303 & $54.7 \%$ \\
\hline Beta-site APP cleaving enzyme & 1455826_a_at & BB114336 & Proteolysis and peptidolysis & 191 & 82.6 & $43.2 \%$ & 135 & $70 \cdot 8 \%$ \\
\hline Synaptonemal complex protein 3 & 1455901_at & Al642069 & Transferase activity & 213 & 474 & $222 \%$ & 165 & $77.5 \%$ \\
\hline Expressed sequence C77892 & 1456112_at & AW554765 & - & 163 & 340 & $208 \%$ & 322 & $197 \%$ \\
\hline RIKEN cDNA $2610205 E 22$ gene & 1456340_at & AV309800 & - & $66 \cdot 6$ & 284 & $427 \%$ & 69.8 & $105 \%$ \\
\hline Basic transcription element binding protein 1 & 1456341_a_at & AV354744 & Transcription & 1290 & 470 & $36.4 \%$ & 754 & $58.4 \%$ \\
\hline Cartilage homeo protein 1 & 1456454_at & BB759122 & & 170 & 36.5 & $21.5 \%$ & 84.4 & $49.6 \%$ \\
\hline cDNA sequence $\mathrm{BC} 038313$ & 1456610_at & AW763746 & & 196 & $75 \cdot 1$ & $38.2 \%$ & 154 & $78.2 \%$ \\
\hline RIKEN cDNA 4933430A16 gene & 1456614_at & BF122715 & & 126 & 290 & $230 \%$ & 119 & $94.4 \%$ \\
\hline RIKEN cDNA E130016E03 gene & 1456674_at & BB772877 & & 500 & 223 & $44.6 \%$ & 475 & $95.0 \%$ \\
\hline Mus musculus transcribed sequences & 1456710_at & BB481932 & & 822 & 383 & $46.6 \%$ & 498 & $60 \cdot 6 \%$ \\
\hline mKIAA0881 protein & 1456826_at & BB313996 & & 254 & 98.9 & $39.0 \%$ & 187 & $73.8 \%$ \\
\hline Dehydrogenase E1 and transketolase & 1457027_at & BB667395 & & 336 & 163 & $48.6 \%$ & 215 & $64.1 \%$ \\
\hline Mus musculus transcribed sequences & 1457110_at & BB440150 & & 180 & 69.2 & $38.3 \%$ & $91 \cdot 1$ & $50 \cdot 5 \%$ \\
\hline Mus musculus transcribed sequences & 1457132_at & BF456117 & & $31 \cdot 2$ & 144 & $462 \%$ & $90 \cdot 0$ & $289 \%$ \\
\hline Mus musculus transcribed sequences & 1457380_at & C85504 & & $62 \cdot 1$ & 184 & $297 \%$ & 75.5 & $122 \%$ \\
\hline Similar to fatty acid desaturase (LOC240957) & 1457403_at & AV378018 & & $88 \cdot 1$ & 194 & $220 \%$ & $76 \cdot 1$ & $86 \cdot 3 \%$ \\
\hline Mus musculus transcribed sequences & 1457520_at & C76369 & Regulation of transcription & $32 \cdot 1$ & 141 & $440 \%$ & 63.3 & $197 \%$ \\
\hline Expressed sequence AV047578 & 1457627_x_at & AV210805 & & $82 \cdot 8$ & 183 & $221 \%$ & 173 & $209 \%$ \\
\hline Clone:B130004P22 product:unclassifiable & 1458099_at & BB291417 & & 504 & 176 & $34.8 \%$ & 298 & $59.1 \%$ \\
\hline Hypothetical protein $1190030 \mathrm{G} 24$ & 1458128_at & BB363084 & & 192 & 436 & $227 \%$ & 304 & $159 \%$ \\
\hline Mus musculus transcribed sequences & 1458304_at & BE985725 & & 121 & 249 & $206 \%$ & 110 & $90 \cdot 7 \%$ \\
\hline Weak similarity to protein ref:NP_038603.1 & 1459015_at & BG079315 & & 1410 & 677 & $48.1 \%$ & 947 & $67 \cdot 3 \%$ \\
\hline
\end{tabular}

${ }^{\text {a } A l l ~ m e a n s ~ a r e ~ f r o m ~} 2$ animals per group. 
Supplementary Table 1m. Effect of CLA isomers on mouse liver gene expression

\begin{tabular}{|c|c|c|c|c|c|c|c|c|}
\hline \multirow[b]{2}{*}{ Gene name } & \multirow[b]{2}{*}{ probe set (Affimetx) } & \multirow[b]{2}{*}{ Accession \# } & \multirow[b]{2}{*}{ Biological function/Process } & \multirow{2}{*}{$\begin{array}{l}\text { Control } \\
\text { Mean }^{\mathrm{a}}\end{array}$} & \multicolumn{2}{|c|}{$\mathrm{t} 10-, \mathrm{c} 12-\mathrm{CLA}$} & \multicolumn{2}{|c|}{ c9-,t11CLA } \\
\hline & & & & & Mean $^{a}$ & $\%$ Control & Mean $^{a}$ & $\%$ Control \\
\hline gb:BG074885/UG_TITLE = ESTs & 1459407_at & BG074885 & & 392 & 955 & $244 \%$ & 331 & $84.6 \%$ \\
\hline $\mathrm{gb}: \mathrm{C} 79743 /$ & 1459468_at & C79743 & & 553 & 264 & $47.8 \%$ & 423 & $76.4 \%$ \\
\hline Carnitine palmitoyltransferase $1 \mathrm{a}$, liver & 1460409_at & Al987925 & Lipid metabolism & 2480 & 1010 & $40.9 \%$ & 2260 & $91.3 \%$ \\
\hline RIKEN cDNA 2610042L04 gene & 1460500_at & AK017182 & & 77.9 & 188 & $241 \%$ & 102 & $131 \%$ \\
\hline cDNA sequence BC010245 & 1460559_at & BB038765 & & 319 & 155 & $48.4 \%$ & 325 & $102 \%$ \\
\hline Fas-activated serine/threonine kinase & 1460635_at & NM_023229 & Apoptosis & 482 & 236 & $48.9 \%$ & 379 & $78.6 \%$ \\
\hline CEA-related cell adhesion molecule 2 & 1460682_s_at & $\mathrm{BC} 024320$ & - & 1470 & 727 & $49.5 \%$ & 1530 & $104 \%$ \\
\hline
\end{tabular}

${ }^{\mathrm{a}}$ All means are from 2 animals per group. 